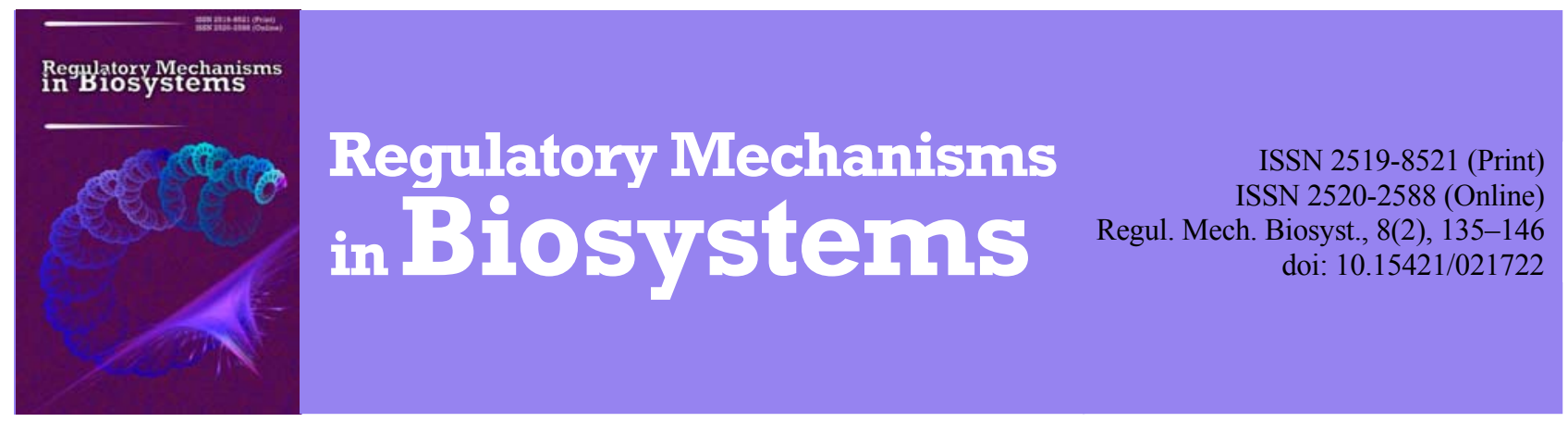

\title{
Mechanism of damage to platelet and erythrocyte hemostasis in rats with prolonged hypokinesia
}

\author{
S. L. Popel'*, O. F. Kryzanivskaya*, V. M. Zhurakivskyi**, R. Y. Chovhan*, U. N. Dutchak**, \\ O. O. Klipich**, Y. I. Klipich**, T. V. Knyazevich-Chorna**, A. V. Sinitsa*, N. O. Zemskaya*, \\ I. V. Melnik**, Y. N. Yatciv*, E. Y. Lapkovskiy*, Y. V. Lutckiy*, N. I. Schovkova** \\ *Precarpathian National University named after V. Stefanik, Ivano-Frankivsk, Ukraine \\ **Ivano-Frankivsk National Medical University, Ivano-Frankivsk, Ukraine
}

Article info

Received 27.03.2017

Received in revised form 17.04.2017

Accepted 23.04.2017

Precarpathian National University named after

V. Stefanik, Shevchenko Str., 57,

Ivano-Frankivsk, 76018, Ukraine

Ivano-Frankivsk National

Medical University

Galitcka Str., 2

Ivano-Frankivsk, 76025, Ukraine

Tel.: +38-097-87-41-446.

E-mail: popelsergij@gmail.com
Popel', S. L., Kryzanivskaya, O. V., Zhurakivskyi, V. M., Chovhan, R. Y., Dutchak, U. N., Klipich, O. O., Klipich, Y. I., Knyazevich-Chorna, T. V., Sinitsa, A. V., Zemskaya, N. O., Melnik, I. V., Yatciv, Y. N., Lapkovskiy, E. Y., Lutckiy, Y. V., \& Schovkova, N. I. (2017). Mechanism of damage to platelet and erythrocyte hemostasis in rats with prolonged hypokinesia. Regulatory Mechanisms in Biosystems, 8(2), 135-146. doi:10.15421/021722

The aim of the study was to determine the morphological changes in the cellular elements of blood in rats of different ages under conditions of prolonged hypokinesia. Research into the structural and functional properties of platelets and erythrocytes was carried out by electron microscope and by biochemical methods in 90 mature male rats aged 2, 12 and 24 months. We found that in young ( 2 month animals) there was a significant increase in the relative content of activated platelets while the normal content of aggregated and degranulated forms with the appearance of single platelets was maintained with an imbalance of alpha and delta granules. In 12-month-old animals, platelet hemostasis disorders were manifested by a significant increase in the relative content of activated platelets (by 125.8$134.7 \%$ ) with an increase in aggregated and degranulated forms, the appearance of numerous platelets with an imbalance of alpha- and delta-granules, and reduction of mitochondria (by 24.9-27.8\%). In 24 month old animals there was a sharp violation of platelet hemostasis due to a significant increase in the content of activated, degranulated and aggregated platelets, the release of the majority of granules, the development of intravascular platelet hyperactivation, an increase in the number of reversible and irreversibly transformed erythrocytes, an increase in the level of aggregation, in particular the appearance of complex cellular aggregates and bizarre forms of red blood cells. The greatest degree of manifestation of morpho-functional changes was revealed in animals aged 24 months, with relative stability of the hemostasis system in 2 and 12 month old animals. Our results showed that irrespective of age, the degree of disturbance of platelet-erythrocyte hemostasis rose as the period of hypokinesia increased and also depended on the increase in the level of serum creatinine. Taken together, intravascular platelet hyperactivation, an imbalance in the content of all types of granules, the transformation of surface cytoarchitectonics of erythrocytes, and the formation of platelet aggregates may play the role of an early predictor of the development of hypokinetic disease.

Keywords: hypokinesia; blood platelet; erythrocytes; hemostasis; ultrastructure

\section{Механізм тромбоцитарно-еритроцитарного гемостазу щурів різного віку за тривалої гіпокінезії}

\author{
С. Л. Попель*, О. Ф. Крижанівська*, В. М. Жураківський**, Р. Я. Човган*, У. М. Дутчак**, \\ О. О. Кліпич**, Я. І. Кліпич**, Т. В. Князевич-Чорна**, А. В. Синиця*, Н. О. Земська*, \\ І. В. Мельник**, Я. М. Яців*, Е. Й. Лапковський*, Я. В. Луцький*, Н. І. Шовкова** \\ *Прикарпатський національний університет імені Василя Стефаника, Івано-Франківськ, Украӥна \\ **Івано-Франківський національний медичний університет, Івано-Франківськ, Україна
}

Мета досліджень полягала у визначенні морфологічних змін клітинних елементів крові у щурів різного віку за тривалої гіпокінезії. Дослідження структурно-функціональних властивостей тромбоцитів та еритроцитів проведені електронномікроскопічними та біохімічними методами на 90 статевозрілих щурах-самцях віком 2, 12 і 24 місяці. У двомісячних тварин відбувається вірогідне збільшення відносного вмісту активованих тромбоцитів зі збереженням нормального вмісту агрегованих і дегранульованих форм і появою поодиноких тромбоцитів із дисбалансом альфа- та дельта-гранул. У 12-місячних тварин порушення тромбоцитарного гемостазу полягають у вірогідному збільшенні відносного вмісту активованих тромбоцитів (на 125,8-134,7\%) 3 підвищенням вмісту агрегованих і 
дегранульованих форм, появою численних тромбоцитів із дисбалансом альфа- та дельта-гранул, а також редукцією мітохондрій (на 24,927,8\%). У 24-місячних тварин спостерігається значна активація тромбоцитарно-еритроцитарної ланки гемостазу за рахунок вірогідного наростання вмісту активованих, дегранульованих і агрегованих тромбоцитів, вивільнення вмісту більшості гранул, розвитку внутрішньосудинної гіперактивації тромбоцитів, збільшення кількості зворотно та незворотно трансформованих еритроцитів, підвищення рівня агрегації, зокрема, появи складних клітинних агрегатів і химерних форм еритроцитів. Найбільший ступінь прояву морфофункціональних змін виявляється у тварин віком 24 місяці, за відносної стійкості системи гемостазу у тварин 2- та 12-місячного віку. Незалежно від віку ступінь порушення тромбоцитарно-еритроцитарного гемостазу підвищується у міру зростання терміну гіпокінезії та залежить також від збільшення рівня креатиніну сироватки крові. У своїй сукупності внутрішньосудинна гіперактивація тромбоцитів, дисбаланс вмісту всіх типів гранул, трансформація поверхневої цитоархітектоніки еритроцитів і формування тромбоцитарних агрегатів можуть відігравати роль раннього предиктора розвитку гіпокінетичної хвороби.

Ключові слова: гіпокінезія; тромбоцит; еритроцит; гемостаз; ультраструктура

\section{Вступ}

Нині серед екстремальних факторів навколишнього середовища, які впливають на структуру та функцію організму, особливо виділяється обмеження рухової активності. При цьому існує досить багато літературних джерел, присвячених вивченню механізмів впливу гіпокінезії, а також розробок заходів профілактики іï шкідливого впливу на організм людини (Zorbas et al., 2012; Tseilikman et al., 2013; Lutfi, 2016).

Однак залишається мало вивченим вплив гіпокінезії на гемостаз. У багатьох публікаціях останніх років, присвячених еритроцитно-тромбоцитарному гемостазу, підкреслюється важливість вихідного морфофункціонального стану клітинних елементів крові для формування адекватних реакцій та зміни гомеостазу. Причин, що зумовлюють гіпокінезію в сучасної людини, багато: професії у високоавтоматизованих і механізованих галузях виробництва, навчання в різноманітних навчальних закладах, звичка до малорухомого способу життя, тривалий ліжковий режим за деяких захворювань (травми, паралічі, інфаркт міокарда, розлади мозкового кровообігу тощо).

Нині відомі різні аспекти негативного впливу гіпокінезії на організм, внаслідок чого з'являються різні морфофункціональні зміни. Перш за все, досліджено порушення опорнорухового апарату та його нейротрофічного забезпечення під час обмеження рухової активності (Jaeger and Jung, 2015). При цьому менше уваги приділяли морфологічній перебудові органів кардіореспіраторної, травної та видільної системи. І зовсім небагато праць присвячено вивченню ендокринної та імунної системи, а також біохімічним змінам за гіпокінезії. Однак у механізмі гіпокінетичних порушень структури майже всіх органів провідну роль відіграють реакція мікросудин та зміни клітинних компонентів крові (Tseilikman et al., 2013). Тому наукову та практичну значимість становить усебічне вивчення впливу гіпокінезії на еритроцитно-тромбоцитарний гемостаз.

Профілактика мікро- та макросудинних ускладнень за гіпокінезії полягає в інтенсивній корекції багатьох розладів, найважливіші $з$ яких - дисфункція ендотелію та порушення внутрішньосудинного еритроцитарно-тромбоцитарного гемостазу (Marks, 2012; Delano et al., 2015).

Важливу роль у патогенезі мікросудинних порушень виконують зміни системи гемостазу та пошкодження реологічної функції - ендотелію судин, тромбоцитів, фібринолізу та гемокоагуляції (Bennett, 2014). Виражені гемореологічні дефекти визначаються навіть на ранніх стадіях гіпокінетичної хвороби та характеризуються підвищенням в'язкості крові та агрегаційної здатності еритроцитів і тромбоцитів, а також фібринолітичної активності плазми крові (Huang et al., 2016). У циркуляції відбувається постійне утворення агрегатів із тромбоцитів, еритроцитів, лейкоцитів, а також конгломератів, що виникають завдяки взаємодії окремих клітин крові між собою (Hayward, 2011).

За даними морфологічних досліджень, у патогенезі багатьох захворювань тією або іншою мірою відіграють роль порушення функції тромбоцитів і еритроцитів. Гіпокінезія та супутні зміни метаболізму викликають аномалії внутрішньоеритроцитарних і мембранних обмінних процесів у тромбоцитах.

Патогенез коагулопатичного синдрому за тривалої гіпокінезії залишається недостатньо вивченим. При цьому деякі автори (Juravlyova et al., 2016) вказують на підвищення агрегаційної здатності тромбоцитів і еритроцитів унаслідок гіперліпідемії та диспротеїнемії, які закономірно виникають за тривалої гіпокінезії (Zorbas et al., 2012; Gainutdinov et al., 2013). Це погіршує реологічні властивості крові, що викликає уповільнення кровообігу та посилення агрегації тромбоцитів і еритроцитів (Korneychuk et al., 2016).

Окремі автори (Lutfi, 2016), вказують, що у людей під час імобілізаційного стресу істотно підвищується внутрішньосудинна активація тромбоцитів на фоні зниження антиагрегантної активності стінки судин, що викликає появу в судинному руслі не тільки тромбоцитарних, а й масивних за своїм клітинним складом тромбоцитарно-еритроцитарних агрегатів із подальшим порушенням мікроциркуляції (Tseilikman et al., 2013). Отже, актуальним залишається з'ясування та подальше розроблення багатьох проблем, пов'язаних з аналізом морфологічного субстрату внутрішньоклітинних процесів та міжклітинних взаємодій, що відбуваються за тривалої гіпокінезії.

Мета роботи - вивчити морфологічні зміни клітинних елементів крові у щурів за тривалої гіпокінезії.

\section{Матеріал і методи досліджень}

Гіпокінезію моделювали в лабораторних щурів лінії Вістар за загальноприйнятою методикою у модифікації Jaeger and Jung (2015). Тварин експериментальної групи поділили на три вікові підгрупи (по 30 тварин у кожній). До складу I підгрупи увійшли 2-місячні щури, до II - 12-місячні, до III - 24-місячні тварини. Тварин виводили 3 експерименту через 90, 180 i 240 діб із початку моделювання гіпокінезії 3 дотриманням загальноприйнятих правил. Контролем служили 45 інтактних тварин (по 15 щурів у кожній підгрупі відповідного віку).

Морфологічне типування клітинних елементів крові здійснювали за рекомендаціями Kitchen and Makris (2010) i Falet (2012).

Для визначення активності ферментів антиоксидантної системи в еритроцитах кров забирали з хвостової вени щомісячно 3 першого по восьмий місяць експерименту. Активність ферментів антиоксидантної системи захисту визначали в гемолізатах еритроцитів. Для лізису використовували $0,01 \%$ розчин сапоніну в $0,01 \mathrm{M} \mathrm{Na-K-фосфатному} \mathrm{буфері}(\mathrm{pH} 7,4)$. Активність каталази визначали за швидкістю утилізації перекису водню за участі FOX-реактиву. За каталазну активність еритроцитів приймали кількість мкмоль субстрату $\left(\mathrm{H}_{2} \mathrm{O}_{2}\right)$, перетворюваного ферментом за хвилину, розраховану на міліграм гемоглобіну $(\mathrm{Hb})$ у пробі, тобто в мкмоль/(хв•мг $\mathrm{Hb})$.

Активність супероксиддисмутази визначали спектрофотометричним методом. Для відображення істинної природи взаємозв'язку між активностями ферментів системи антиоксидантного захисту аналізували їх співвідношення.

Для ультраструктурного аналізу видаляли прямий м'яз стегна та тромбоцити зі збагаченої фракції плазми крові, які використовували для подальшого дослідження відповідно до рекомендацій Ali (2015). Для виготовлення епоксидних блоків використовували композицію епон-аралдіт. Зрізи одержували на ультрамікротомі УМТП-6М (Selmi, Україна). Дослідження проводили за допомогою трансмісійного електронного мікроскопа ПЕМ100K (Selmi, Україна) з прискорювальною напругою 75 кВ за 
збільшень 2 000-80 000 разів. У цілому, електронномікроскопічне дослідження проводили за стандартною схемою (Mio et al., 2016).

Вивчення поверхневої цитоархітектоніки еритроцитів і тромбоцитів венозної крові проводили за допомогою сканувальною електронного мікроскопа JEOL-25A-T3225 (Японія) 3 прискорювальною напругою 20 кВ. Тварин утримували в умовах віварію згідно $з$ нормативними документами.

Для статистичної обробки результатів застосовували пакет Statistica 6.1 (StatSoft Inc., USA). Для порівняння дослідних груп (залежно від типу статистичного розподілу) брали парний t-критерій Стьюдента або його непараметричний аналог критерій Уїлкоксона. Оцінювання відповідності розподілу величин нормальному (Гаусса) проводили за допомогою коефіцієнтів ексцесу та асиметрії.

\section{Результати}

В усіх тварин незалежно від віку максимум активності супероксиддисмутази припадає на 90-ту добу експерименту, коли ії концентрація в 1,8-2,1 раза перевищує дані контрольної групи. Через 180 діб із початку моделювання гіпокінезії активність супероксиддисмутази знижується, однак залишається в 1,4-1,5 раза вищою за контроль, проте до 240-ї доби активність ферменту була нижчою за контроль на $45-50 \%(\mathrm{P}<0,05)$. Інша динаміка показників спостерігається в активності каталази, коли виявляються два максимуми: перший - через 90 діб, дру- гий - через 210 діб із початку моделювання гіпокінезії (рис. 1). Порівняно з контрольними тваринами біохімічний склад крові змінюється також за рахунок підвищення рівня креатиніну, яке залежить від віку щурів і терміну гіпокінезії. У тварин І групи рівень креатиніну підвищується на $12,4 \%$ через 90 діб, на $19,8 \%$ - через 180 діб і на 24,6\% - через 240 діб після початку моделювання гіпокінезії. Значно менші коливання спостерігаються у щурів II вікової групи: відповідно на $8,9 \%, 12,1 \%$ i $18,4 \%(\mathrm{P}<0,05)$. Найбільші зміни виявляються у тварин III групи, в яких рівень креатиніну підвищується відповідно на $14,6 \%, 22,7 \%$ i $28,2 \%(\mathrm{P}<0,05)$.

Одночасно з біохімічними змінами спостерігається структурна перебудова клітинних компонентів крові. При цьому у щурів I підгрупи через 90 діб після початку моделювання гіпокінезії кількість дегранульованих тромбоцитів зросла у 2,87 раза $(\mathrm{P}<0,05)$. Це відбувається за рахунок вивільнення переважно альфа-гранул, тому частка активованих і агрегованих тромбоцитів більше ніж удвічі перевищувала значення контрольної групи (табл. 1). У складі тромбоцитарного пулу цих тварин виявляли лише поодинокі форми клітин із помітним дисбалансом альфа- та дельта-гранул, а також змінами в умісті лізосом і ультраструктури мітохондрій. Фрагменти тромбоцитів і псевдоподії спостерігали в невеликій кількості. У переважної більшості тварин морфологія хромомера тромбоцитів свідчить про незначний ступінь порушення тромбоцитарно-еритроцитарного гемостазу (рис. $2 a, \sigma)$.

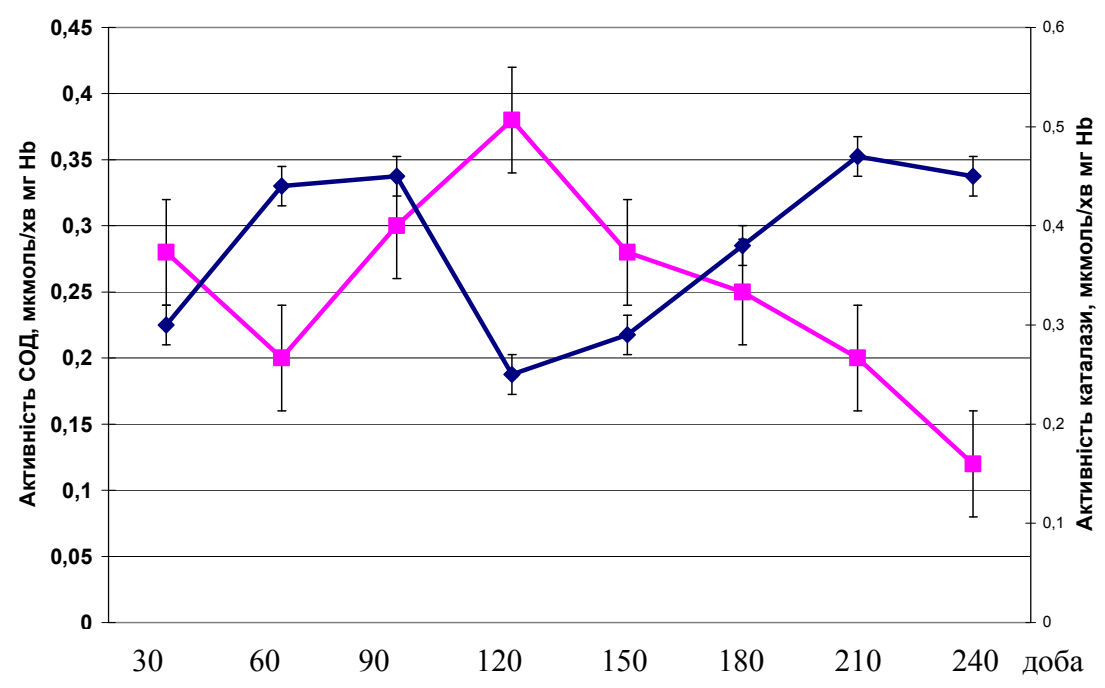

Рис. 1. Зміна активності основних ферментів системи антиоксидантного захисту еритроцитів у різні терміни тривалої гіпокінезії: СОД - супероксиддисмутаза

У тварин I підгрупи через 180 діб спостерігали значні патологічні зміни тромбоцитів, які супроводжувалися істотною гетероморфністю тромбоцитарного пулу за його функціональною гіперактивністю та змінами структури хромомера більшості тромбоцитів. Вказані зміни свідчать про те, що за гіпокінезії часто розвивається псевдоподіальний та, рідше, гіаліновий тип морфологічної трансформації тромбоцитів (рис. 3,4$)$.

Визначення морфології циркулюючих агрегатів крові виявило наявність значної кількості функціонально активних поліморфноядерних лейкоцитів у складі агрегатів із розвиненими псевдоподіями, численними фагосомами та їх комплексами зі специфічними та неспецифічними гранулами. Разом із цим, присутність незрілих форм нейтрофілів підтверджувала наявність як ендотеліальної дисфункції, так і активного внутрішньоклітинного запалення. Про розвиток запального процесу свідчила також значна частка активованих еозинофілів у складі тромбоцитарно-лейкоцитарних агрегатів. Такі еозинофіли разом зі зрілими гранулами та характерним кристалоїдом високої електронної щільності містили поліморфні зерна значно менших розмірів поблизу ядра.

Зустрічали також частково дегранульовані клітини із залишками лабільних гранул під цитолемою. Слід зазначити, що разом зі значним підвищенням частки агрегованих тромбоцитів спостерігали наявність великих сферичних форм із новоутвореними псевдоподіями, ознаками дестабілізації зовнішньої мембрани та істотним розширенням відкритої системи канальців. Глибокі ділянки цієї системи містили аморфний матеріал помірної електронної щільності, який кількісно значно перевищує вміст альфа-гранул.

У щурів I групи через 240 діб спостерігали істотне зниження вмісту нормальних дископодібних тромбоцитів щодо контролю (на $24,2 \%, \mathrm{P}<0,05)$ за рахунок різкого наростання кількості дискоехіноцитів, сфероцитів і сфероехіноцитів, що викликало підвищення вмісту активних клітин удвічі $(\mathrm{P}<0,05)$. Установлено пропорційне наростання в циркуляції малих тромбоцитарних агрегатів, тоді як великі тромбоцитарні агрегати не утворюються. Кількісна оцінка вмісту зворотно та незворотно конформованих еритроцитів також не виявила істотних змін у тварин цісй вікової підгрупи порівняно з контрольною групою.

У щурів II групи через 90 діб гіпокінезії знайдено значну активацію тромбоцитарної ланки гемостазу та пошкодження тинкторіальних властивостей еритроцитів. Частка активованих 
тромбоцитів у цій групі тварин перевищувала рівень контрольної групи майже в 2,5 раза (табл. 2). Також різко підвищеним виявився рівень агрегованих і дегранульованих форм. За рахунок цього вміст неактивованих тромбоцитів крові поступався контрольному показнику на 45,2\% (P <0,05).

Утворення дегранульованих форм відбувалося переважно за рахунок вивільнення альфа-гранул. Ступінь вказаних патоморфологічних змін значною мірою залежав від рівня креати- ніну у плазмі крові. У складі тромбоцитарного пулу крові тварин II групи виявлялася незначна кількість тромбоцитів 3 істотним дисбалансом альфа- та дельта-гранул, а також ультраструктурними змінами лізосом і мітохондрій. Фрагменти тромбоцитів і псевдоподії спостерігали в помірній кількості. У переважної більшості тварин цієї групи морфологія хромомера тромбоцитів свідчить про обмежено розвинений ступінь порушень тромбоцитарного гемостазу (рис. 5).

\section{Таблиця 1}

Морфометричні показники клітинних елементів крові у щурів I вікової групи за тривалої гіпокінезії порівняно з контрольною групою тварин $(\mathrm{x} \pm \mathrm{SE})$

\begin{tabular}{|c|c|c|c|c|}
\hline \multirow{2}{*}{ Параметри } & \multirow{2}{*}{$\begin{array}{c}\text { Контрольна } \\
\text { група }\end{array}$} & \multicolumn{3}{|c|}{ Експериментальна группа: термін експерименту, діб } \\
\hline & & 90 & 180 & 240 \\
\hline \multicolumn{5}{|c|}{ Тромбоцити } \\
\hline Неактивні тромбоцити, \% & $76,15 \pm 3,33$ & $44,93 \pm 2,11^{*}$ & $41,02 \pm 2,16^{*}$ & $37,92 \pm 1,73^{*}$ \\
\hline Агреговані тромбоцити, \% & $6,79 \pm 0,53$ & $14,39 \pm 1,05^{*}$ & $17,08 \pm 1,34^{*}$ & $18,31 \pm 1,17^{*}$ \\
\hline Активні тромбоцити, \% & $15,99 \pm 1,27$ & $35,95 \pm 2,17 *$ & $41,53 \pm 2,15^{*}$ & $40,11 \pm 2,33^{*}$ \\
\hline Активовані тромбоцити, \% & $23,97 \pm 1,85$ & $54,24 \pm 2,14^{*}$ & $58,89 \pm 3,71^{*}$ & $62,04 \pm 3,02 *$ \\
\hline Біполярні тромбоцити, \% & $0,55 \pm 0,03$ & $0,77 \pm 0,03$ & $0,89 \pm 0,07^{*}$ & $1,15 \pm 0,11^{*}$ \\
\hline Дегранульовані тромбоцити, \% & $5,93 \pm 1,11$ & $16,87 \pm 1,15^{*}$ & $18,55 \pm 1,33^{*}$ & $20,02 \pm 1,54^{*}$ \\
\hline Дрібні тромбоцитарні агрегати & $3,15 \pm 0,11$ & $6,18 \pm 0,52 *$ & $12,01 \pm 1,17^{*}$ & $14,36 \pm 1,14 *$ \\
\hline Великі тромбоцитарні агрегати & $0,17 \pm 0,01$ & $0,21 \pm 0,01$ & $2,62 \pm 0,14^{*}$ & $4,41 \pm 0,83^{*}$ \\
\hline Альфа-гранули, мкм ${ }^{3}$ мкм $^{3}$ & $0,105 \pm 0,011$ & $0,076 \pm 0,012 *$ & $0,066 \pm 0,008^{*}$ & $0,057 \pm 0,003 *$ \\
\hline Дельта-гранули, мкм $^{3} /$ мкм $^{3}$ & $0,033 \pm 0,007$ & $0,031 \pm 0,009$ & $0,029 \pm 0,005$ & $0,025 \pm 0,005^{*}$ \\
\hline Лізосоми, мкм $^{-2}$ & $0,141 \pm 0,011$ & $0,124 \pm 0,002$ & $0,119 \pm 0,001$ & $0,096 \pm 0,010^{*}$ \\
\hline Мітохондрії, мкм ${ }^{3} /$ мкм $^{3}$ & $0,023 \pm 0,005$ & $0,021 \pm 0,005$ & $0,017 \pm 0,003 *$ & $0,014 \pm 0,002 *$ \\
\hline \multicolumn{5}{|c|}{ Еритроцити } \\
\hline Дискоцити, \% & $89,71 \pm 3,51$ & $63,22 \pm 3,92 *$ & $57,59 \pm 3,21^{*}$ & $51,97 \pm 2,40^{*}$ \\
\hline Дискоехіноцити, \% & $10,28 \pm 1,54$ & $22,85 \pm 1,61 *$ & $25,74 \pm 2,68^{*}$ & $29,09 \pm 1,37^{*}$ \\
\hline Сфероцити, \% & $1,88 \pm 0,32$ & $6,04 \pm 0,82 *$ & $8,61 \pm 1,05^{*}$ & $10,81 \pm 0,75^{*}$ \\
\hline Сфероехіноцити, \% & $1,72 \pm 0,24$ & $2,44 \pm 0,52 *$ & $2,83 \pm 0,33 *$ & $3,12 \pm 0,14^{*}$ \\
\hline Зворотно змінені еритроцити, \% & $6,34 \pm 0,23$ & $11,93 \pm 0,85$ & $12,84 \pm 0,92 *$ & $12,72 \pm 0,94^{*}$ \\
\hline Незворотно змінені еритроцити, \% & $2,69 \pm 0,11$ & $2,98 \pm 0,22$ & $3,23 \pm 0,11^{*}$ & $4,01 \pm 0,15^{*}$ \\
\hline
\end{tabular}

Примітка: * - вірогідна різниця з контрольними показниками $\mathrm{P}<0,05$.
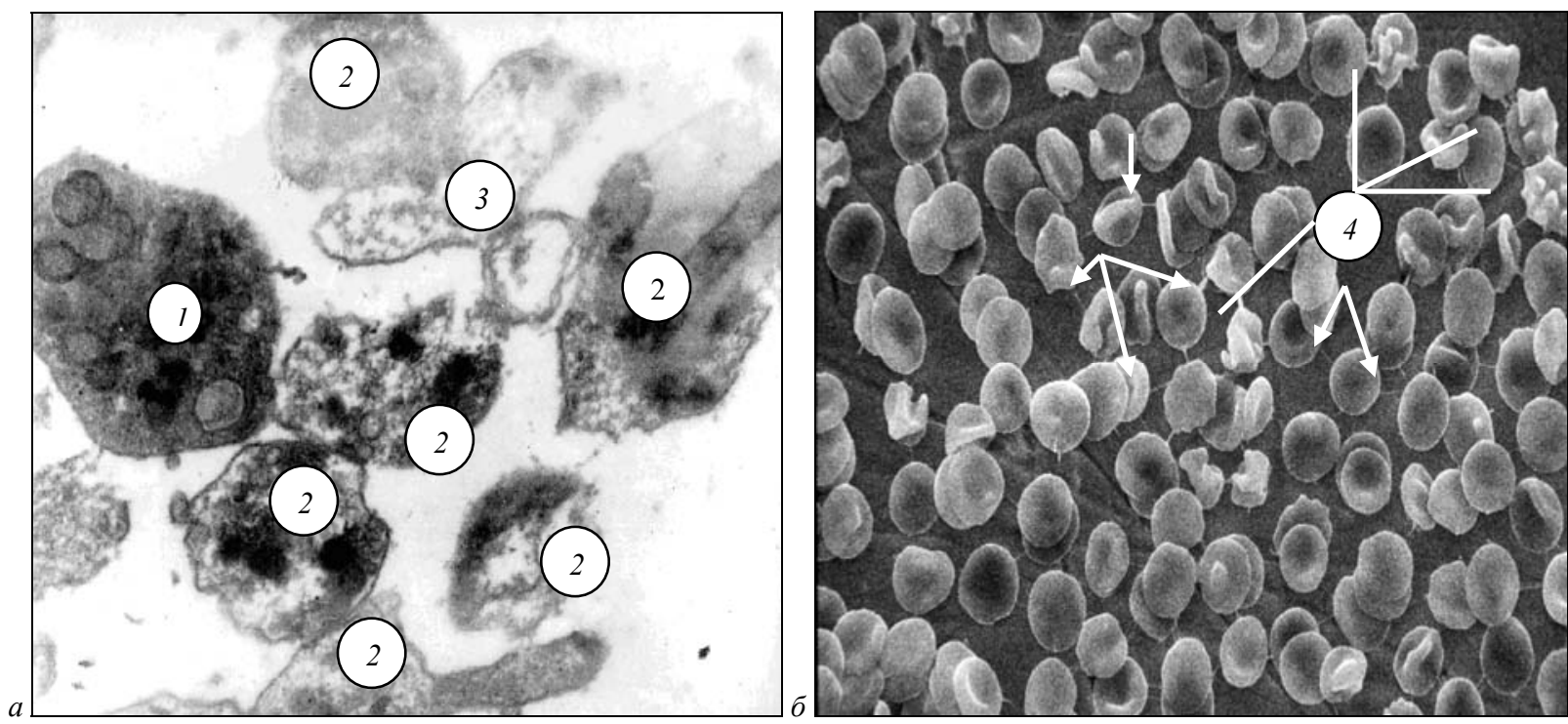

Рис. 2. Ультраструктура тромбоцитів (a) та еритроцитів (б) периферичної крові щурів I підгрупи через 90 діб із початку моделювання тривалої гіпокінезії: 1 - неактивний тромбоцит, 2 - активований тромбоцит, 3 - «тінь тромбоцита», 4 - дегенеративні форми еритроцитів; стрілками показано «нитки агрегації» між окремими еритроцитами; $a$ - трансмісійна електронна мікроскопія, $\sigma$ - сканувальна електронна мікроскопія; $a-15000, \sigma-2000$

На відміну від тварин попереднього терміну експерименту, у щурів II групи через 180 діб із початку моделювання гіпокінезії виявляли значніші зміни тромбоцитів, які проявляються істотною гетероморфністю тромбоцитарного пулу за його функціональною гіперактивністю. При цьому зміни структури хромомера у більшості тромбоцитів відбуваються на фоні їх морфологічної трансформації за псевдоподіальним типом (рис. 6, 7).

Крім того, у тварин II групи через 180 діб із початку моделювання гіпокінезії з підвищенням креатиніну плазми крові збільшується кількість складних агрегатів, які мають значну кількість еритроцитів. Серед них переважали незворотно трансформовані форми - куполоподібні та сфероцити, а також еритроцити у вигляді «спущеного м'яча» та ехіноцити.

За даними трансмісійної електронної мікроскопії, кількість малих тромбоцитарних агрегатів у 3,7 раза перевищувала показник контрольної групи. У тварин у даний термін дослідження виявляли середні та великі агрегати, які в окремих випадках містили лейкоцити або еритроцити. Ультраструктурним дослідженням 
дегранульованих тромбоцитів поблизу цитолеми виявляли численні лабільні гранули із фрагментованими мембранами.

Такі постклітинні форми, на відміну від агрегованих тромбоцитів, переважно зустрічалися поза складом агрегатів. Також спостерігали появу великих сферичних форм із наявністю новоутворених псевдоподій на поверхні, ознаками дестабілізації зовнішньої мембрани та істотним розширенням відкритої канальцевої системи. Глибокі ділянки цієї системи містять аморфний матеріал

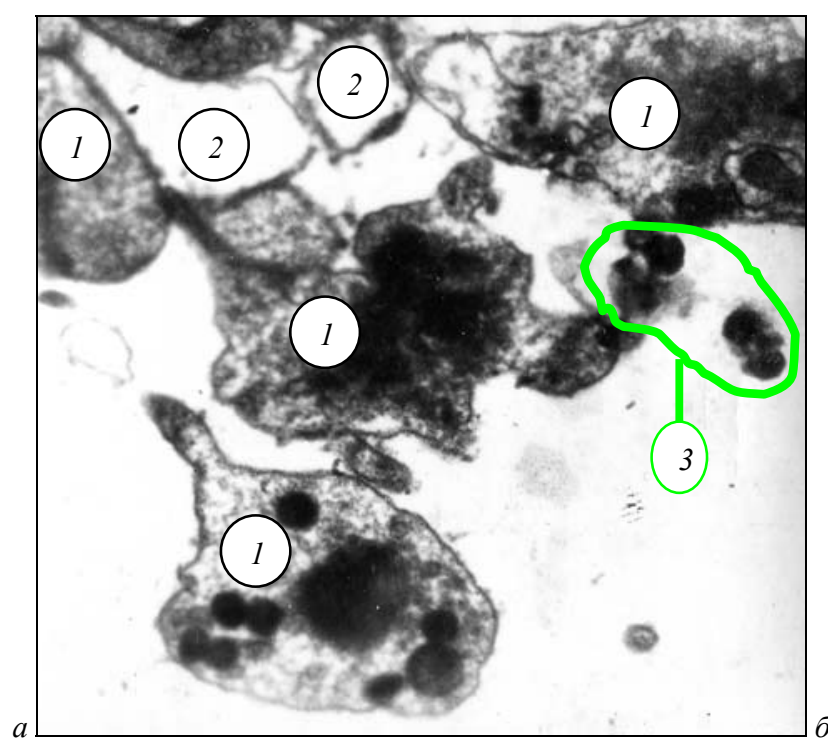

помірної електронної щільності. Кількість щільних тілець перевищувала вміст альфа-гранул. При цьому кількість лізосом і мітохондрій зменшується порівняно з неактивними тромбоцитами.

У щурів II групи через 240 діб спостерігали зниження вмісту нормальних дископодібних еритроцитів за рахунок різкого наростання кількості дискоехіноцитів, сфероцитів і сфероехіноцитів. Також установлено значне збільшення кількості тромбоцитарних агрегатів найрізноманітніших розмірів.

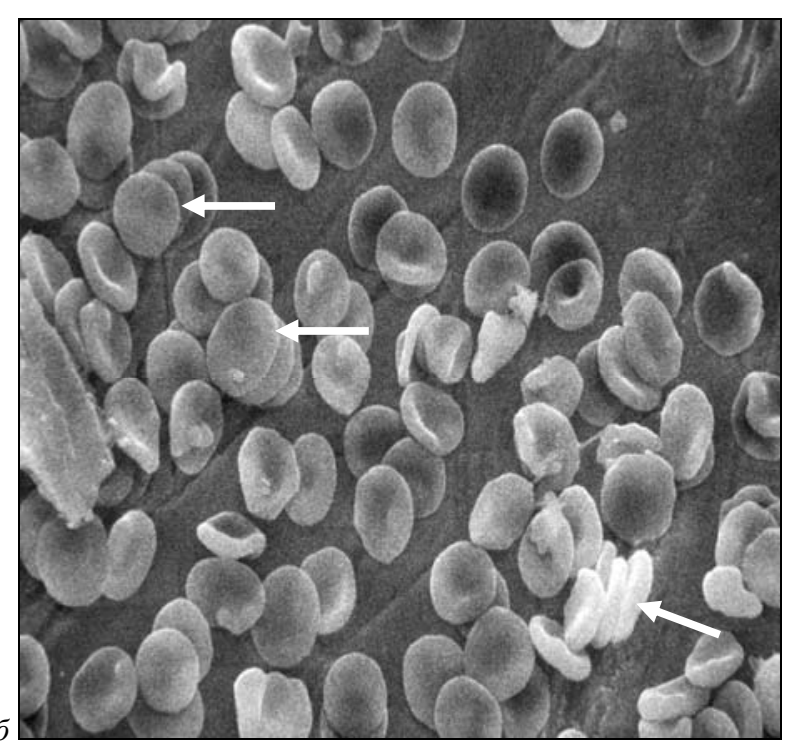

Рис. 3. Ультраструктура тромбоцитів (a) та еритроцитів (б) периферичної крові щурів I групи через 180 діб із початку моделювання тривалої гіпокінезії: 1 - активований тромбоцит, 2 - «тінь тромбоцита», 3 - вільні гранули тромбоцитів; стрілками показано еритроцитарні сладжі у вигляді «монетних стовпчиків»; $a$ - трансмісійна електронна мікроскопія, $\sigma$ - сканувальна електронна мікроскопія; $a-{ }^{\mathrm{x}} 15000, \sigma-{ }^{\mathrm{x}} 2000$
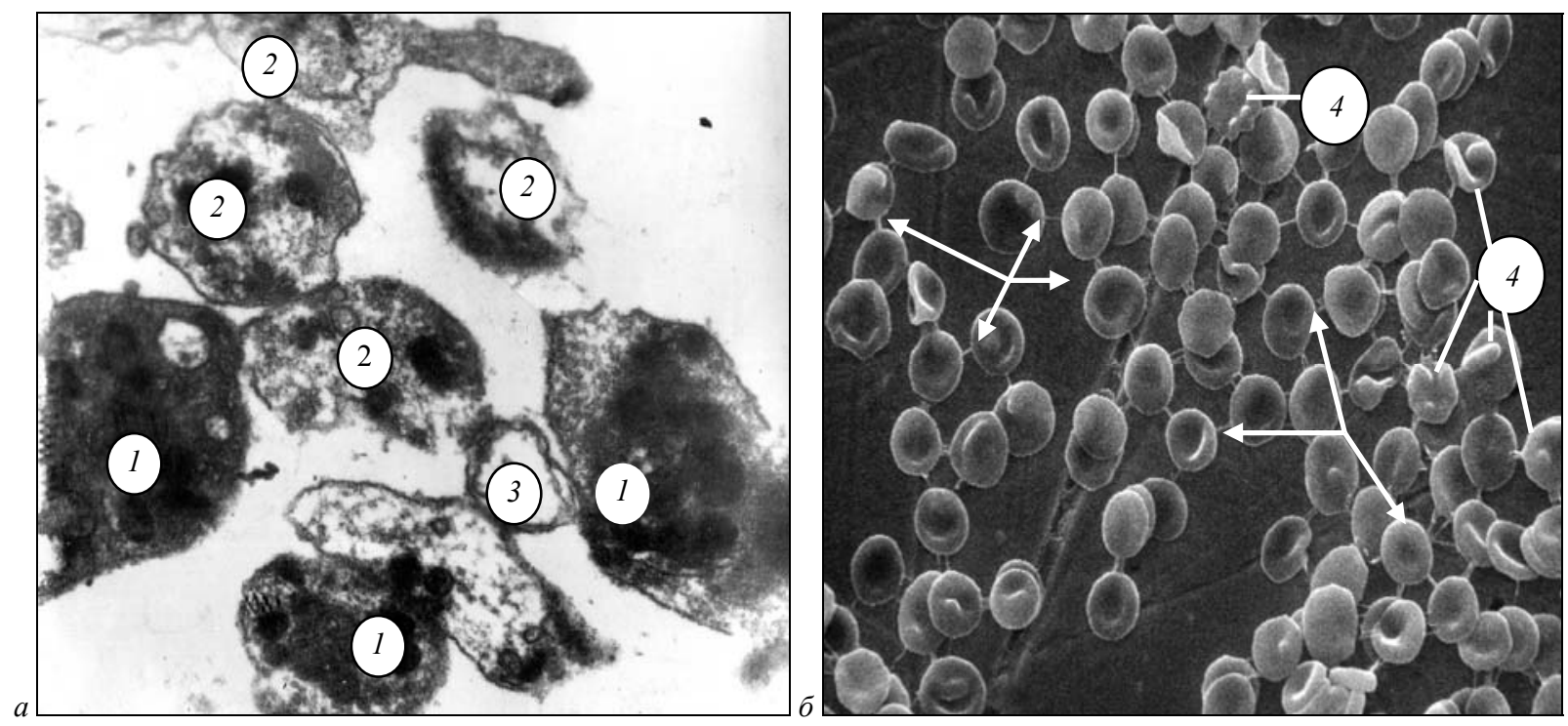

Pис. 4. Ультраструктура тромбоцитів ( $a$ ) та еритроцитів (б) периферичної крові щурів I групи через 240 діб із початку моделювання тривалої гіпокінезії: 1 - неактивний тромбоцит, 2 - активований тромбоцит, 3 - «тінь тромбоцита», 4 - дегенеративні форми еритроцитів; стрілками показано численні «нитки агрегації» між окремими еритроцитами;

$a$ - трансмісійна електронна мікроскопія, $\sigma$ - сканувальна електронна мікроскопія; $a-{ }^{\mathrm{x}} 15000, \sigma$ - ${ }^{\mathrm{x}} 2000$

Структурний аналіз клітинних елементів крові у тварин III групи через 90 діб виявив значну морфологічну перебудову тромбоцитів. Зокрема, частка активованих тромбоцитів підвищувалася більше ніж у 2,5 раза порівняно 3 показниками контрольної групи. Спостерігається також значне (у 2,7 раза) зростання кількості активованих форм (рис. 8).

Дегранульовані тромбоцити за відносним вмістом у 3,2 раза перевищували показник контрольної групи за рахунок вивільнення альфа-гранул і дельта-гранул, а також вірогідного зменшення вмісту лізосом і мітохондрій (табл. 3).
У цілому, у складі тромбоцитарного пулу тварин III групи через 180 діб із початку моделювання гіпокінезії виявили численні тромбоцити 3 помітним дисбалансом альфа- та дельта-гранул, а також зміни лізосом і ультраструктури мітохондрій.

У значній кількості зустрічали фрагменти тромбоцитів i розгалужені псевдоподії на поверхні клітин. У більшості тварин морфологія хромомера тромбоцитів свідчила про виражений ступінь порушень тромбоцитарного гемостазу (рис. 9).

У тварин III групи через 240 діб спостерігали різку активацію тромбоцитів, які супроводжувалися їх істотною гетероморфністю. 
У більшості тромбоцитів це проявляється функціональною гіперактивністю та змінами структури хромомера на фоні обмеженої здатності утворювати псевдоподії (рис. 10). Поряд із цим спостерігали апоптоз ендотеліоцитів і підвищений рівень агрегації клітин- них елементів крові (рис. 11). Морфологічно великі за розмірами циркулюючі агрегати відповідали структурі складних утворень, які містять еритроцити химерної форми. Часто спостерігали частково дегранульовані тромбоцити із залишками лабільних гранул.

\section{Таблиця 2}

Морфометричні показники клітинних елементів крові у щурів II групи за тривалої гіпокінезії порівняно з контрольною групою тварин (x $\pm \mathrm{SE})$

\begin{tabular}{|c|c|c|c|c|}
\hline \multirow{2}{*}{ Параметри } & \multirow{2}{*}{$\begin{array}{c}\text { Контрольна } \\
\text { група } \\
\end{array}$} & \multicolumn{3}{|c|}{ Експериментальна группа: термін експерименту, діб } \\
\hline & & 90 & 180 & 240 \\
\hline \multicolumn{5}{|c|}{ Тромбоцити } \\
\hline Неактивні тромбоцити, \% & $75,41 \pm 4,61$ & $47,34 \pm 4,32 *$ & $44,11 \pm 3,37^{*}$ & $39,12 \pm 2,14^{*}$ \\
\hline Агреговані тромбоцити, \% & $6,82 \pm 0,54$ & $10,65 \pm 1,23^{*}$ & $14,03 \pm 1,27^{*}$ & $16,34 \pm 1,12 *$ \\
\hline Активні тромбоцити, \% & $16,72 \pm 1,22$ & $25,43 \pm 3,11 *$ & $31,33 \pm 2,15^{*}$ & $39,24 \pm 2,58^{*}$ \\
\hline Активовані тромбоцити, \% & $22,23 \pm 1,73$ & $33,15 \pm 2,11^{*}$ & $40,22 \pm 2,16^{*}$ & $50,32 \pm 2,06^{*}$ \\
\hline Біполярні тромбоцити, \% & $0,55 \pm 0,01$ & $0,59 \pm 0,03$ & $0,72 \pm 0,04$ & $0,93 \pm 0,07 *$ \\
\hline Дегранульовані тромбоцити, \% & $6,29 \pm 0,31$ & $8,31 \pm 1,07 *$ & $11,55 \pm 1,71^{*}$ & $16,83 \pm 1,91^{*}$ \\
\hline Дрібні тромбоцитарні агрегати & $3,14 \pm 0,12$ & $4,57 \pm 0,43^{*}$ & $8,36 \pm 1,12 *$ & $11,37 \pm 1,85^{*}$ \\
\hline Великі тромбоцитарні агрегати & $0,18 \pm 0,02$ & $0,19 \pm 0,03$ & $0,41 \pm 0,09 *$ & $1,25 \pm 0,03 *$ \\
\hline Альфа-гранули, мкм ${ }^{3} /$ мкм $^{3}$ & $0,108 \pm 0,022$ & $0,082 \pm 0,006^{*}$ & $0,074 \pm 0,006^{*}$ & $0,061 \pm 0,005^{*}$ \\
\hline Дельта-гранули, мкм ${ }^{3} /$ мкм $^{3}$ & $0,037 \pm 0,011$ & $0,034 \pm 0,008$ & $0,031 \pm 0,007$ & $0,027 \pm 0,005^{*}$ \\
\hline Лізосоми, мкм ${ }^{-2}$ & $0,142 \pm 0,008$ & $0,131 \pm 0,005$ & $0,126 \pm 0,004$ & $0,119 \pm 0,005^{*}$ \\
\hline Мітохондрії, мкм ${ }^{3} /$ мкм $^{3}$ & $0,024 \pm 0,006$ & $0,022 \pm 0,004$ & $0,019 \pm 0,003^{*}$ & $0,016 \pm 0,002 *$ \\
\hline \multicolumn{5}{|c|}{ Еритроцити } \\
\hline Дискоцити, \% & $84,61 \pm 3,17$ & $78,12 \pm 4,04^{*}$ & $68,71 \pm 2,11^{*}$ & $63,15 \pm 2,11^{*}$ \\
\hline Дискоехіноцити, \% & $11,67 \pm 0,85$ & $15,72 \pm 1,24^{*}$ & $20,23 \pm 1,37^{*}$ & $25,17 \pm 1,23^{*}$ \\
\hline Сфероцити, \% & $2,93 \pm 0,11$ & $3,06 \pm 0,32 *$ & $5,03 \pm 0,19 *$ & $8,24 \pm 1,56^{*}$ \\
\hline Сфероехіноцити, \% & $1,66 \pm 0,02$ & $1,83 \pm 0,21 *$ & $2,21 \pm 0,15^{*}$ & $2,99 \pm 0,33^{*}$ \\
\hline Зворотно змінені еритроцити, \% & $9,56 \pm 0,88$ & $10,97 \pm 0,81$ & $12,03 \pm 0,77^{*}$ & $14,01 \pm 1,77^{*}$ \\
\hline Незворотно змінені еритроцити, \% & $2,73 \pm 0,15$ & $2,85 \pm 0,11$ & $3,07 \pm 0,25^{*}$ & $4,33 \pm 0,21 *$ \\
\hline
\end{tabular}

Примітка: * - вірогідна різниця з контрольними показниками $\mathrm{P}<0,05$.

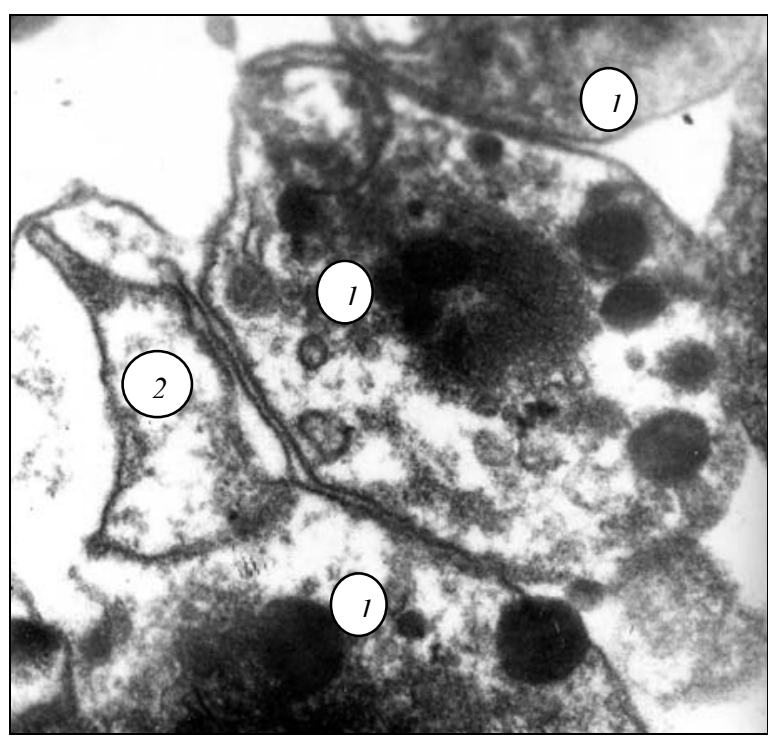

$a$

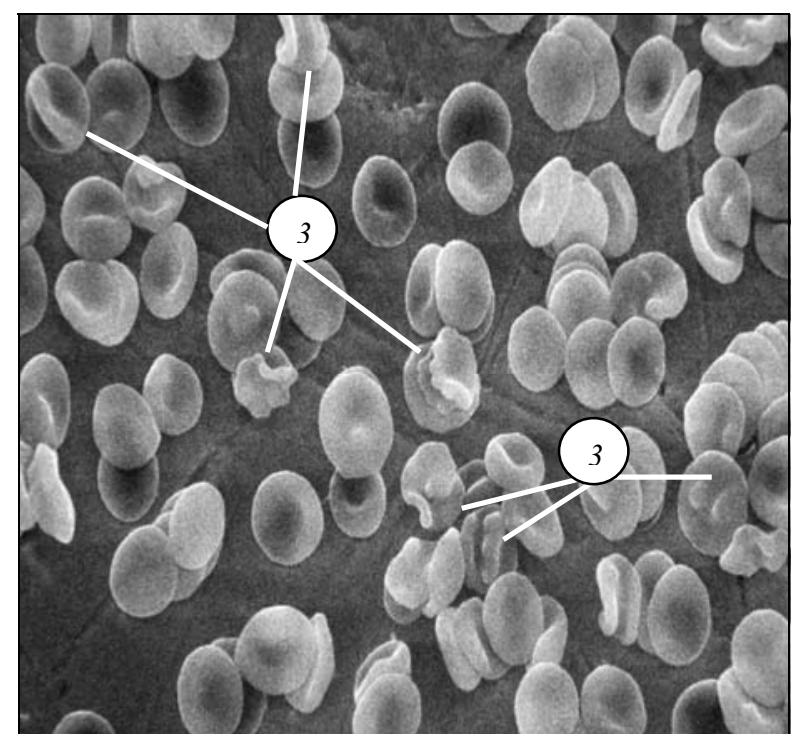

$\sigma$

Рис. 5. Ультраструктура тромбоцитів (a) та еритроцитів (б) периферичної крові щурів II групи через 90 діб із початку моделювання тривалої гіпокінезії: 1 - активований тромбоцит, 2 - «тінь тромбоцита», 3 - дегенеративні форми еритроцитів; $a$ - трансмісійна електронна мікроскопія, $\sigma$ - сканувальна електронна мікроскопія; $a-{ }^{\mathrm{x}} 15000, \sigma$ - ${ }^{\mathrm{x}} 2000$

У сканувальному електронному мікроскопі циркулюючі агрегати виявляються у формі дрібних груп еритроцитів і тромбоцитів, часто зміненої форми, які помітні на оголеній базальній мембрані та, як правило, вкриті густою сіткою фібрину (рис. 11в, г). Разом зі значно підвищеним рівнем агрегованих тромбоцитів спостерігали появу великих сферичних форм із псевдоподіями та ознаками дестабілізації зовнішньої мембрани. Мембрани канальців часто фрагментовані. При цьому цитолема тромбоцитів втрачала цілісність на ділянках, які контактували з іншими клітинами у складі агрегатів. У тварин цієї вікової групи концентрація малих тромбоцитарних агрегатів крові в середньому в 4,7 раза перевищувала значення контрольної групи. У цих тварин також спостерігали різке (у 4,4 раза) перевищення контрольних значень вмісту середніх і великих тромбоцитарних агрегатів.

Реєстрували статистично вірогідне $(\mathrm{P}<0,05)$ зниження вмісту нормальних дископодібних еритроцитів (на $36,7 \%$ ) за рахунок різкого зростання кількості дискоехіноцитів (у 2,7 раза), сфероцитів (у 3,8 раза) і сфероехіноцитів (у 1,9 раза), що відбувається на фоні значного (у 2,5 раза) підвищення вмісту активних форм тромбоцитів, зворотно та незворотно трансформованих еритроцитів - на 50,4\% і 25,5\% (P <0,05) відповідно.

\section{Обговорення}

Для розкриття патогенетичних механізмів формування пошкоджень на тканинному та клітинному рівні істотний інтерес 
становить вивчення ролі гемостазу в забезпеченні адаптаційних реакцій організму під час іммобілізаційного стрессу, оскільки еритроцити та тромбоцити, тісно контактуючи з усіма тканинами та вступаючи 3 ними у морфофункціональні взаємовідносини, власною кількісною та якісною перебудовою відображають фізіологічні та патологічні зміни, що відбуваються в організмі під час різних функціональних станів, у тому числі при гіпокінезії. Тільки окремі автори присвятили дослідження ви-

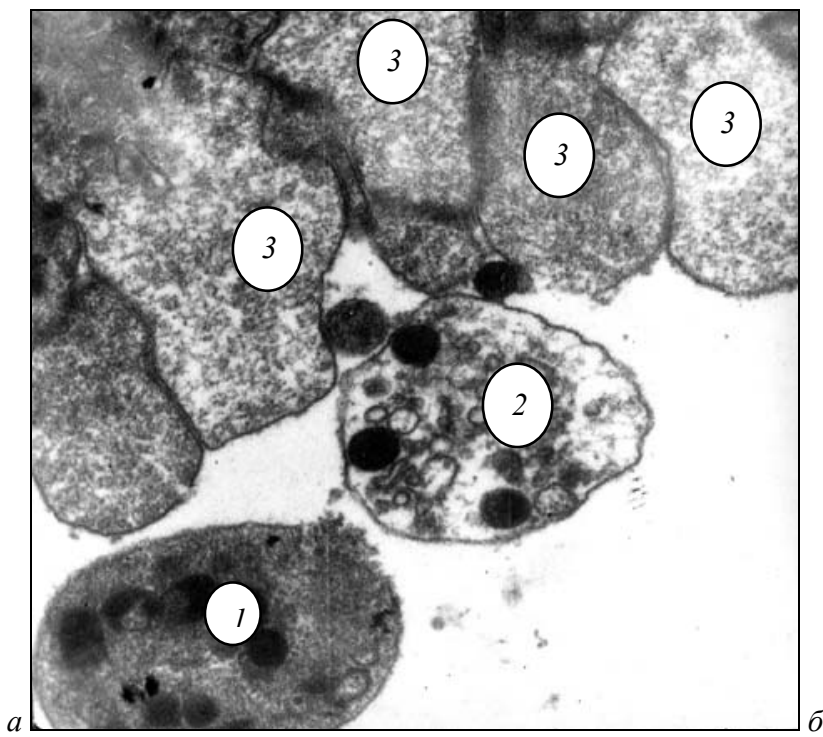

вченню гемостазу за гіпокінезії у людини та тварин (Zorbas et al., 2012; Juravlyova et al., 2016). Однак вони досліджували гемостатичну функцію крові тільки в короткі терміни гіпокінезії (протягом 15-30 діб). При цьому встановлено, що зниження цієї функції за коротокотривалої гіпокінезії супроводжується розвитком гіпокоагуляції, механізм якого пов'язаний зі зниженням активності факторів згортання плазми крові та функції тромбоцитів.

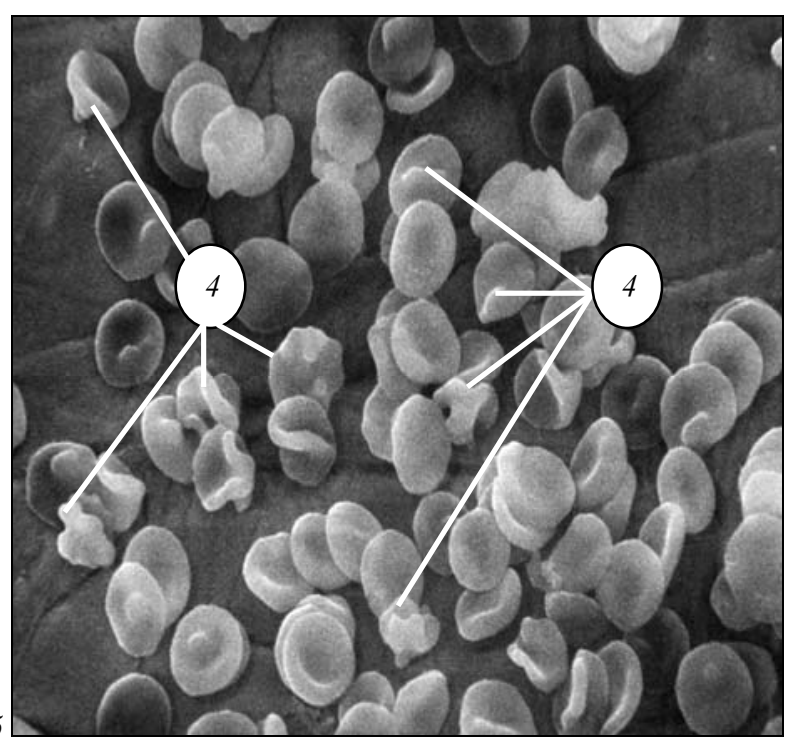

Рис. 6. Ультраструктура тромбоцитів ( $a$ ) та еритроцитів (б) периферичної крові щурів II групи через 180 діб із початку моделювання тривалої гіпокінезії: 1 - неактивний тромбоцит, 2 - активований тромбоцит, 3 - «тінь тромбоцита»,

4 - дегенеративні форми еритроцитів; $a$ - трансмісійна електронна мікроскопія, $\sigma$ - сканувальна електронна мікроскопія; $a-{ }^{\mathrm{x}} 15000, \sigma-{ }^{\mathrm{x}} 2000$
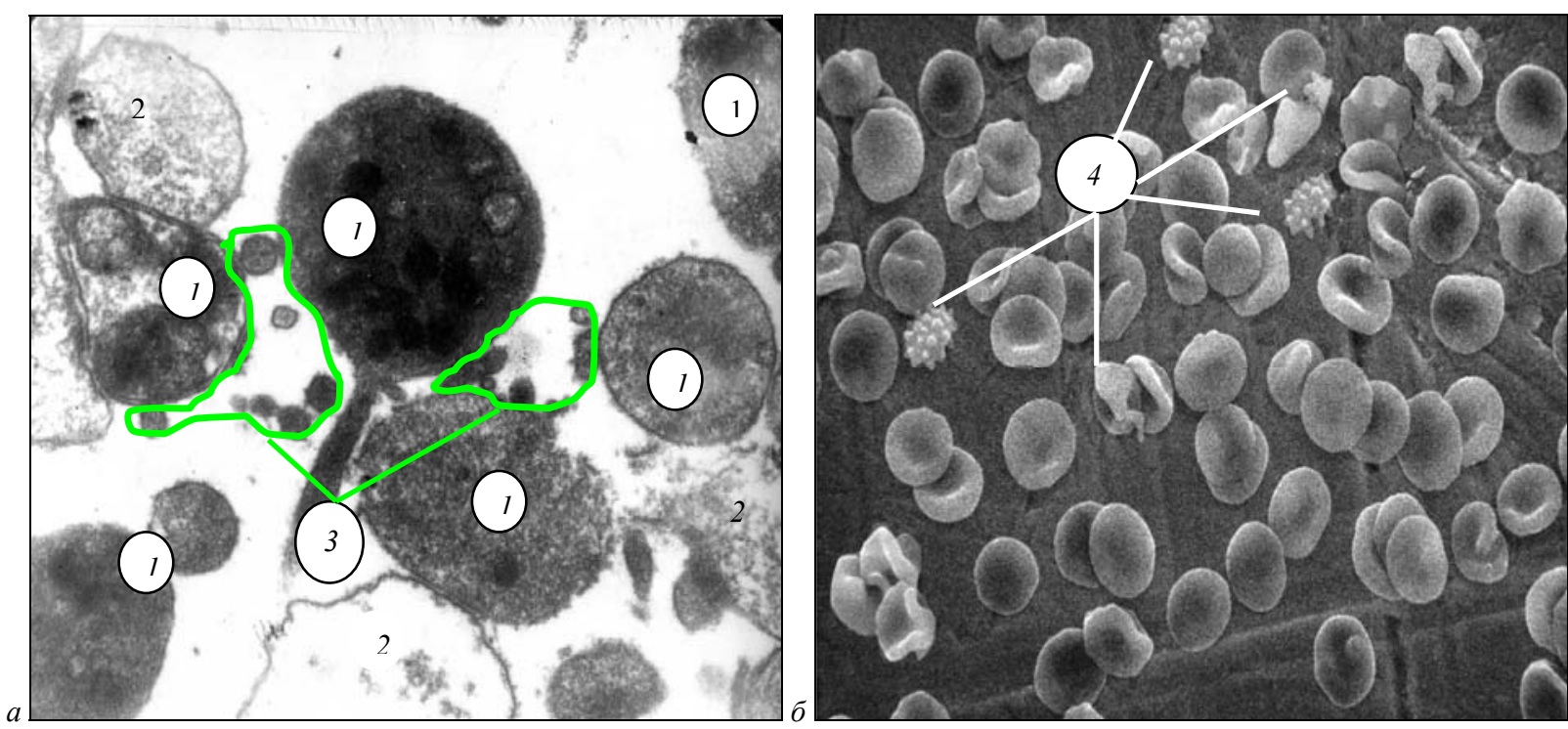

Рис. 7. Ультраструктура тромбоцитів ( $a$ ) та еритроцитів (б) периферичної крові щурів II групи через 240 діб із початку моделювання тривалої гіпокінезії: 1 - активований тромбоцит, 2 - «тінь тромбоцита», 3 - вільні гранули, 4 - дегенеративні форми еритроцитів; $a$ - трансмісійна електронна мікроскопія, $\sigma$ - сканувальна електронна мікроскопія; $a-{ }^{\mathrm{x}} 15000, \sigma$ - ${ }^{\mathrm{x}} 2000$

Gainutdinov et al. (2013) показали, що в реадаптаційному періоді після 30-денної гіпокінезії в людей гіпокоагуляція змінюється підвищенням тромботвірної функції крові, причини та механізм якої залишаються мало вивченими. Невідомі також причини фазних змін гемостазу (з гіпокоагуляції на період гіперкоагуляції крові), що відіграє важливу роль у розвитку тромбгеморагічного синдрому за тривалої гіпокінезії.

Разом із тим, гіпокінезія (Stogov, 2009; Juravlyova et al., 2016) порушує гемокоагуляцію тільки за рахунок порушення концентрації факторів згортання у плазмі крові, а отже, збільшує ризик розвитку кровотечі, але не тромбозів (Duan et al., 2014). Додаткові екстремальні дії (емоційний стрес, оперативне лікування з наступним тривалим ліжковим режимом у разі іммобілізації нижніх кінцівок або тіла в цілому) сприяють прискоренню безперервного внутрішньосудинного згортання крові до ступеня дисемінованого внутрішньосудинного згортання крові (Marcus, 2012; Delano et al., 2015) - тобто викликають гемостатичні зрушення, що вимагають корекції.

Таким чином, дані літератури відносно характеру та механізмів розвитку гемостатичної функції крові за гіпокінезії мають іноді діаметрально протилежні погляди; при цьому механізм цих порушень за тривалої гіпокінезії залишається мало вивченим. 
Тому наше дослідження направлене на вивчення не стільки плазматичних факторів, як на тромбоцитарну ланку гемостазу у поєднанні з вивченням ролі еритроцитів та біохімічних факторів, які впливають на гемостаз за тривалої гіпокінезії та можуть запускати механізм тромбемболічних ускладнень, на які вказують багато авторів (Lieberman et al., 2014).

Порівняно з контрольною групою активність супероксиддисмутази та каталази змінюється залежно від терміну досліду та не

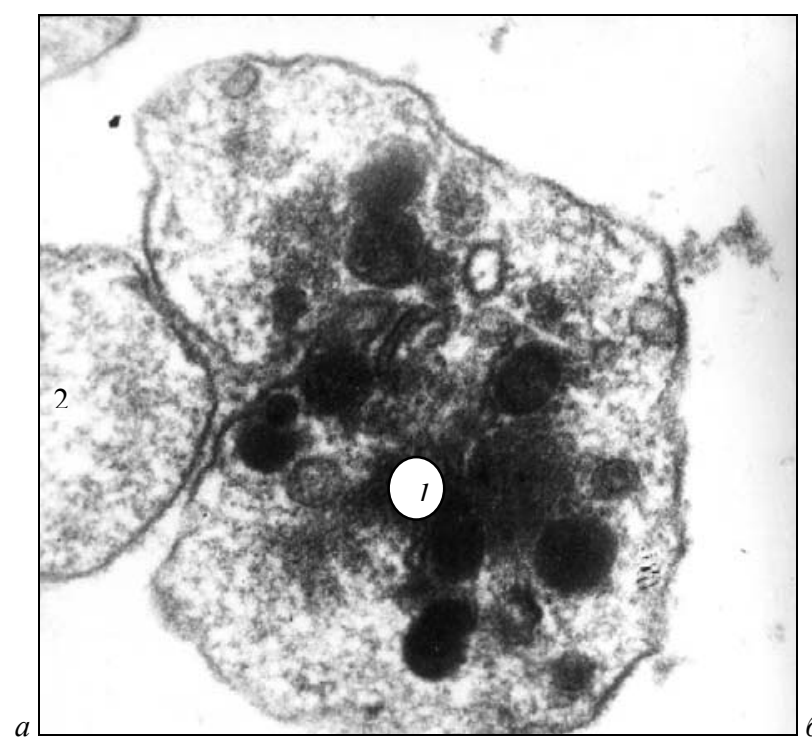

залежить від вікової групи. При цьому зростання каталазної активності відбувається на фоні вірогідного зниження активності супероксиддисмутази. Перехресна активність цих ферментів пояснюється певною особливістю антиоксидантної системи захисту еритроцитів, в якій для каталази супероксидний аніон-радикал - негативний ефектор, а перекисні сполуки - позитивний, тоді як для супероксиддисмутази - навпаки. Згідно $з$ даними Stogov (2009), така різнонаправлена зміна їх активності характерна для гіпоксії.

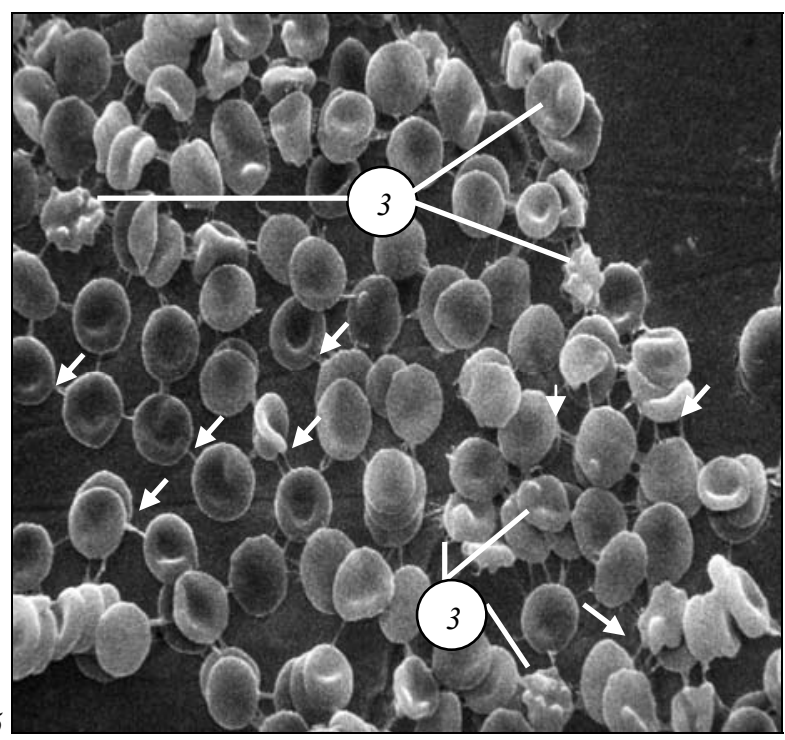

Рис. 8. Ультраструктура тромбоцитів (a) та еритроцитів (б) периферичної крові щурів III групи через 90 діб після початку моделювання тривалої гіпокінезії: 1 - активований тромбоцит, 2 - «тінь тромбоцита», 3 - дегенеративні форми еритроцитів; стрілками показано «нитки адгезії»; $a$ - трансмісійна електронна мікроскопія, $\sigma$ - скануюча електронна мікроскопія;

$$
a-{ }^{\mathrm{x}} 15000, \sigma-{ }^{\mathrm{x}} 2000
$$

Таблиця 3

Морфометричні показники клітинних елементів крові у щурів III вікової групи за тривалої гіпокінезії порівняно з контрольною групою тварин, $\mathrm{x} \pm \mathrm{SE}$

\begin{tabular}{|c|c|c|c|c|}
\hline \multirow{2}{*}{ Параметри } & \multirow{2}{*}{$\begin{array}{c}\text { Контрольна } \\
\text { група }\end{array}$} & \multicolumn{3}{|c|}{ Експериментальна группа: Термін експерименту, діб } \\
\hline & & 90 & 180 & 240 \\
\hline \multicolumn{5}{|c|}{ Тромбоцити } \\
\hline Неактивні тромбоцити, \% & $74,93 \pm 8,25$ & $39,86 \pm 4,42 *$ & $33,41 \pm 4,55^{*}$ & $30,11 \pm 3,17^{*}$ \\
\hline Агреговані тромбоцити, \% & $6,38 \pm 0,54$ & $14,02 \pm 2,56^{*}$ & $19,53 \pm 2,27 *$ & $24,33 \pm 1,75^{*}$ \\
\hline Активні тромбоцити, \% & $16,97 \pm 2,53$ & $39,71 \pm 3,79 *$ & $50,28 \pm 4,44 *$ & $54,51 \pm 4,39 *$ \\
\hline Активовані тромбоцити, \% & $24,56 \pm 1,64$ & $55,36 \pm 4,82 *$ & $60,22 \pm 6,84 *$ & $63,67 \pm 5,17 *$ \\
\hline Біполярні тромбоцити, \% & $0,51 \pm 0,01$ & $0,83 \pm 0,05$ & $0,93 \pm 0,07$ & $1,05 \pm 0,17^{*}$ \\
\hline Дегранульовані тромбоцити, \% & $6,25 \pm 0,91$ & $17,97 \pm 2,31 *$ & $19,58 \pm 2,22 *$ & $26,15 \pm 2,33 *$ \\
\hline Дрібні тромбоцитарні агрегати & $3,54 \pm 0,52$ & $7,19 \pm 1,53 *$ & $12,73 \pm 1,65^{*}$ & $14,76 \pm 1,84^{*}$ \\
\hline Великі тромбоцитарні агрегати & $1,09 \pm 0,03$ & $1,22 \pm 0,14$ & $2,74 \pm 0,18^{*}$ & $4,81 \pm 0,33^{*}$ \\
\hline Альфа-гранули, мкм³/мкм³ & $0,107 \pm 0,011$ & $0,069 \pm 0,007^{*}$ & $0,063 \pm 0,005^{*}$ & $0,051 \pm 0,003^{*}$ \\
\hline Дельта-гранули, мкм³/мкм ${ }^{3}$ & $0,036 \pm 0,002$ & $0,028 \pm 0,006$ & $0,026 \pm 0,004$ & $0,022 \pm 0,002 *$ \\
\hline Лізосоми, мкм ${ }^{-2}$ & $0,141 \pm 0,017$ & $0,111 \pm 0,003$ & $0,108 \pm 0,031$ & $0,091 \pm 0,011 *$ \\
\hline Мітохондрії, мкм ${ }^{3} / \mathrm{MKм}^{3}$ & $0,023 \pm 0,005$ & $0,016 \pm 0,007$ & $0,011 \pm 0,003 *$ & $0,010 \pm 0,002 *$ \\
\hline \multicolumn{5}{|c|}{ Еритроцити } \\
\hline Дискоцити, \% & $83,47 \pm 4,11$ & $60,32 \pm 4,06^{*}$ & $65,14 \pm 6,62^{*}$ & $62,37 \pm 2,25^{*}$ \\
\hline Дискоехіноцити, \% & $12,02 \pm 1,52$ & $26,17 \pm 3,33^{*}$ & $30,15 \pm 2,41^{*}$ & $31,42 \pm 2,66$ \\
\hline Сфероцити, \% & $3,03 \pm 0,17$ & $6,88 \pm 1,14^{*}$ & $9,23 \pm 1,77^{*}$ & $11,11 \pm 2,03 *$ \\
\hline Сфероехіноцити, \% & $1,93 \pm 0,35$ & $3,15 \pm 0,73 *$ & $3,79 \pm 0,81^{*}$ & $4,02 \pm 0,84^{*}$ \\
\hline Зворотно змінені еритроцити, \% & $10,02 \pm 1,34$ & $15,61 \pm 1,73$ & $17,93 \pm 1,85^{*}$ & $18,81 \pm 2,73^{*}$ \\
\hline Незворотно змінені еритроцити, \% & $3,01 \pm 0,15$ & $3,73 \pm 0,21$ & $4,67 \pm 0,23^{*}$ & $5,24 \pm 0,32 *$ \\
\hline
\end{tabular}

Примітка: * - вірогідна різниця з контрольними показниками $(\mathrm{p}<0,05)$.

Про роль гіпоксії у розвитку структурних змін у різні терміни гіпокінезії вказують тільки окремі автори (Makáry et al., 1987), а результати цих досліджень фрагментарні, вимагають поглибленого розгляду та узагальнення.

Проведений нами статистичний аналіз вказує на існування вірогідної негативної кореляції між активністю супероксиддисмутази та каталази еритроцитів у тварин усіх вікових підгруп, тоді як у контрольних тварин зафіксовано високу $(\mathrm{r}=0,86)$ позитивну кореляцію між активністю цих ферментів. На наш погляд, це може підтвердити думку окремих авторів, які додатковим джерелом молекулярного кисню за гіпоксії вважають процес відновлення перекису водню, що розцінюється як компенсаторно-пристосувальна реакція цілісного організму на гіпоксію та гіпокінезію (Маkáry et al., 1987). Оскільки каталаза компенсаторно підвищує коефіцієнт утилізації кисню, то для енергетичної доцільності зменшення концентрації супероксиддисмутази необхідне для часткового повернення в метаболічні реакції того молекулярного кисню, який відновлюється в організмі за одноелектронним шляхом, по- 
силюючи при цьому процеси окисного фосфорилювання. Багато авторів (Zorbas et al., 2012) одностайні щодо важливої ролі процесів перекисного окиснення в загальній патогенетичній схемі розвитку гіпокінетичної хвороби. Відомості про зв'язок перекисного окиснення ліпідів із гемостазом (Krause, 2016) і прооксидантні властивості фізичного навантаження (Lutfi, 2016) дозволяють говорити про значну роль депривації фізичного навантаження за тривалої гіпокінезії в розвитку гіперкоагулемії. На думку Tseilikman et al. (2013), вона викликається накопиченням статевих стероїдів (естрогенів) на фоні зменшення концентрації андрогенів, що закономірно спостерігається за тривалої гіпокінезії (Stogov, 2009). Це дозволяє обгрунтувати перспетиви подальших досліджень характеру впливу гіпокінезії на еритроцитарно-тромбоцитарний

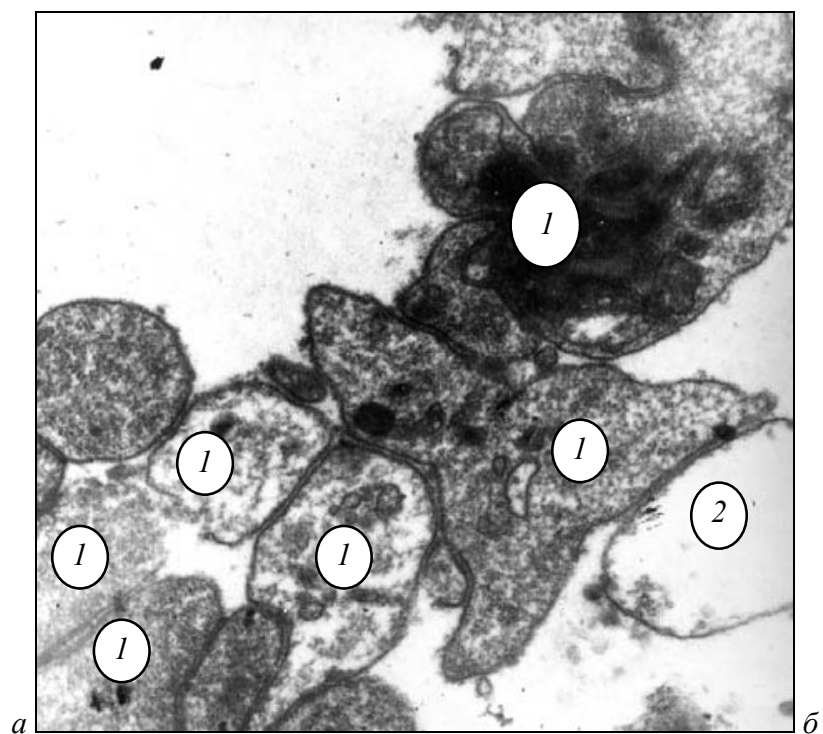

та біохімічний компоненти гемостазу, фібриноліз, реакцію безперервного внутрішньосудинного згортання крові та оцінити можливість корекції гемостатичних зрушень фізичним навантаженням у перспективі подалыших досліджень. Установлені нами підвищення концентрації продуктів перекисного окиснення ліпідів та окисної модифікації білків узгоджуються $з$ даними наукової літератури (Neelamegham, 2012; Juravlyova et al., 2016; Krause, 2016) i свідчать про їх вплив на структурну перебудову клітинного компонента системи гемостазу. При цьому зміна біохімічного складу крові за рахунок підвищення рівня креатиніну свідчить про посилений розпад м'язової тканини в умовах тривалої гіпокінезії (Stogov, 2009) і тісно корелює зі змінами еритроцитарно-тромбоцитарного гемостазу.

Рис. 9. Ультраструктура тромбоцитів (a) та еритроцитів (б) периферичної крові щурів III групи через 180 діб із початку моделювання тривалої гіпокінезії: 1 - активований тромбоцит, 2 - «тінь тромбоцита», 3 - дегенеративні форми еритроцитів, 4 - фібрин; стрілками показано «дірчасті» еритроцити; $a$ - трансмісійна електронна мікроскопія, $\sigma$ - сканувальна електронна мікроскопія; $a-{ }^{\mathrm{x}} 15000, \sigma-{ }^{\mathrm{x}} 2000$
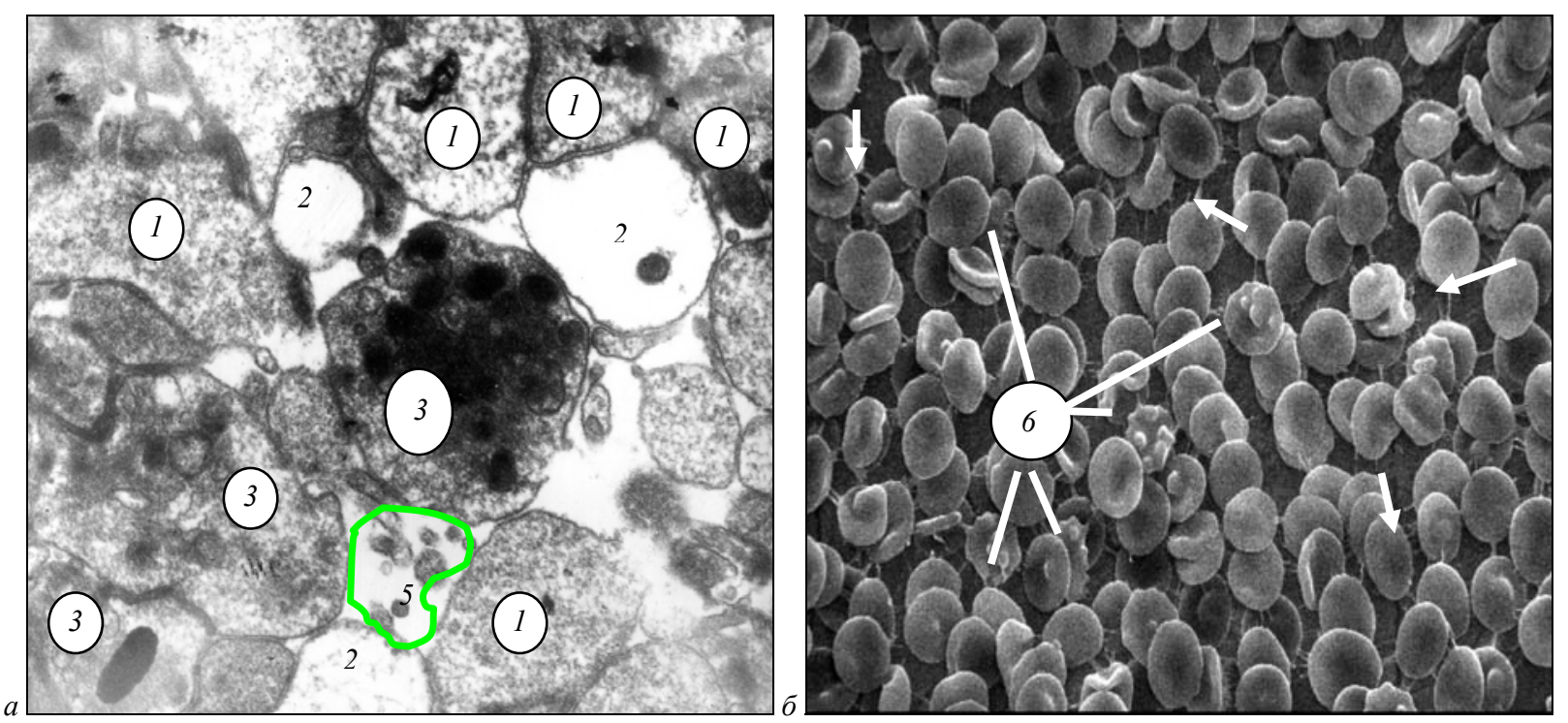

Рис. 10. Ультраструктура тромбоцитів (a) та еритроцитів (б) периферичної крові щурів III групи через 240 діб від початку моделювання тривалої гіпокінезії: 1 - активований тромбоцит, 2 - «тінь тромбоцита», 3 - тромбоцити у стадії зворотної активації, 4 - неактивний тромбоцит, 5 - секреторні гранули, 6 - дегенеративні форми еритроцитів; стрілками показано «нитки адгезії»; $a$ - трансмісійна електронна мікроскопія, $\sigma$ - сканувальна електронна мікроскопія; $a-{ }^{\mathrm{x}} 15000, \sigma-{ }^{\mathrm{x}} 2000$

Згідно з нашими даними, за гіпокінезії спостерігається ендотеліальна дисфункція, що $є$ предиктором виникнення багатьох захворювань серцево-судинної системи, а також захворювань інших органів та систем. Тому це може бути причиною багатьох ускладнень за тривалої гіпокінезії (Zorbas et al., 2012). У сучасних дослід- женнях вказується на такий механізм розвитку ендотеліальної дисфункціï (Gainutdinov et al., 2013): 1) дефіцит оксиду азоту в ендотелії, пов'язаний із підвищенням порушення або зниженням продукції ендотеліального оксиду азоту, 2) порушення структури та функцій ендотеліальної NO-синтетази, 3) зниження чутливості 
до NO. У результаті цього порушується метаболізм ендотеліоцитів, з активацією механізмів апоптозу (Leytin, 2012), тому на більшому чи меншому протязі судинної стінки оголяється базальна мембрана. За контакту рецепторів адгезії тромбоцитів із субстратом і дією синтезованого в ділянці пошкодження судинної стінки тромбіну починається активація тромбоцитів (Gainutdinov et al., 2013). Імовірно, основну роль у первинній активації тромбоцитів відіграє сигнал із рецепторів GPIa-IIa, GPIb-V-IX и GPVI, які контактують зі своїми агоністами, у першу чергу з колагеном, фактором Віллебранда та тромбіном (Vitkovsky and Strambovska- уа, 2014). Крім колагену, властивістю активувати тромбоцити володіють також інші субендотеліальні структури (Marcus, 2012). На нашу думку, саме ці фактори впливають на конформацію тромбоцитів, оскільки показано, що за тривалої гіпокінезії тромбоцити можуть проходити різні стадії контактної активації, переходячи 3 неактивної форми у вигляді дискоцита чи пластинки, у зворотну стадію з перетворенням на кулеподібну форму із псевдоподіями та в незворотну стадію адтезії у вигляді розплесканих форм без внутрішньоклітинного вмісту - «тінь тромбоцита» (Місhelson, 2013).
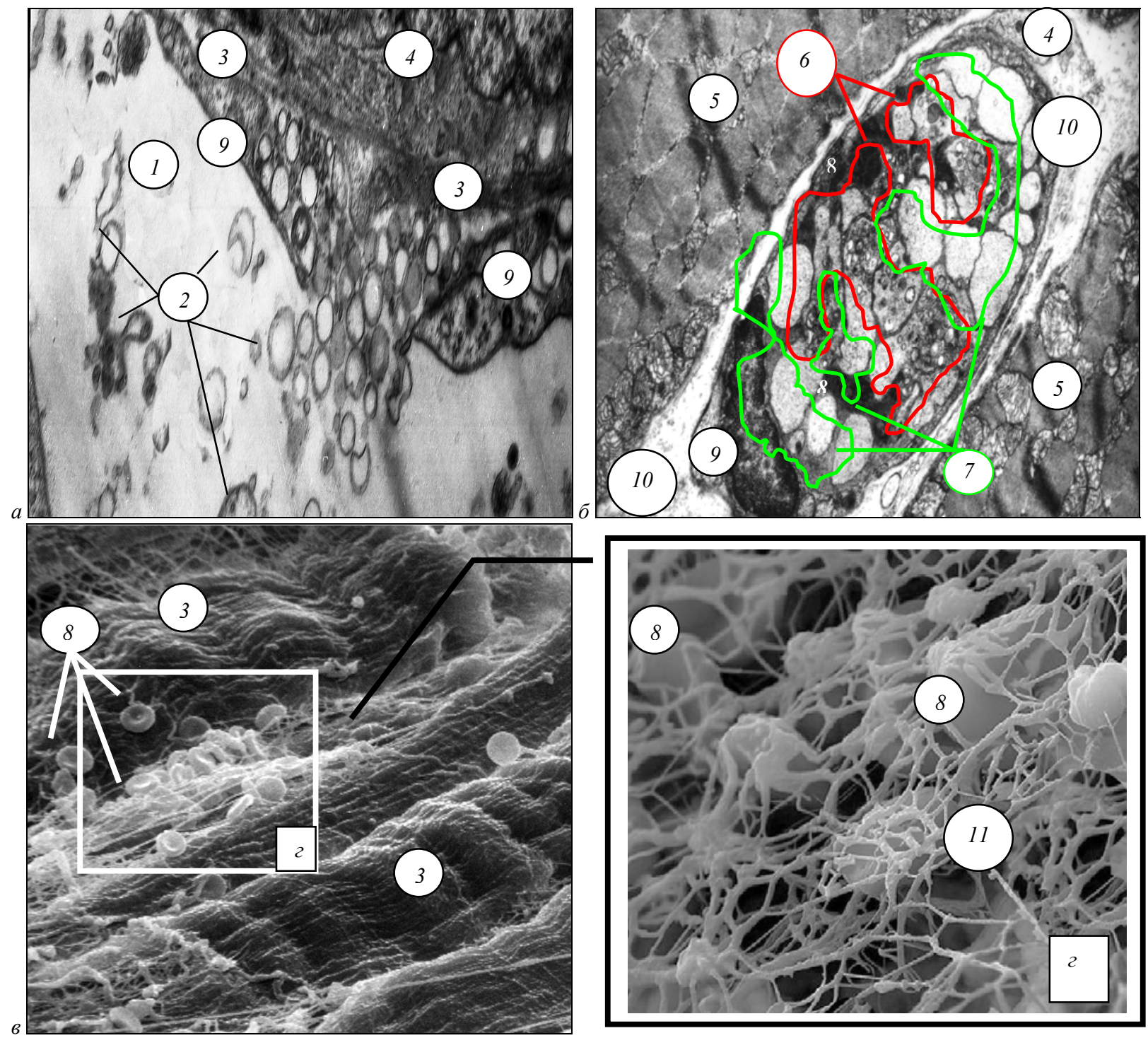

Рис. 11. Ультраструктурна картина апоптозу ендотеліоцита $(a)$ та внутрішньосудинного мікротромба в гемокапілярі прямого м'яза стегна (б) та в ділянці деендотелізації базальної мембрани $(6,2)$ у щура III вікової групи через 240 діб із початку моделювання гіпокінезії: 1 - просвіт гемокапіляра, 2 - апоптозні тільця, 3 - базальна мембрана, 4 - перицит, 5 - м'язове волокно, 6 - активовані тромбоцити, 7 - «тіні тромбоцитів», 8 - еритроцит, 9 - ендотеліоцит, 10 - ендомізій, 11 - нитки фібрину; $a, \sigma$ - трансмісійна електронна мікроскопія, 6,2 - сканувальна електронна мікроскопія; $a$ - ${ }^{\mathrm{x}} 15000, \sigma-{ }^{\mathrm{x}} 8000,6$ - ${ }^{\mathrm{x}} 5000,2$ - ${ }^{\mathrm{x}} 10000$

Активація тромбоцитів лежить в основі виконання ними своїх функцій (Peter, 2010; Rao, 2013; Pitchford, 2015). Багато речовин, які входять до списку основних речовин, що активують тромбоцити, можуть синтезуватися за гіпокінезії, особливо тривалої (Stogov, 2009). Майже всі ці речовини взаємодіють із тромбоцитами через специфічні рецептори, описані Lieberman et al. (2014). Незважаючи на різноманіття активаторів і значну кількість рецепторів до них, клітина має обмежену кількість шляхів передачі сигналу та ефекторних механізмів (Vitkovsky and Strambovskaya, 2014). Реакція тромбоцита на активувальний вплив однотипна: спочатку тромбоцит змінює форму, на його поверхні з'являються псевдоподії, він «роз- плескується» за рахунок відкритої канальцевої системи збільшується площа їх поверхні. Змінюються співвідношення різних фосфоліпідів між зовнішнім і внутрішнім листками клітинної мембрани. Це викликає появу на зовнішній поверхні тромбоцита значної кількості кислих фосфоліпідів із прокоагулянтними властивостями - фактор III тромбоцитів $\left(\mathrm{PF}_{3}\right)$. На мембрані тромбоцитів экспресуються або підвищують свою афінність інтегрини (Naik et al., 2013; Kasirer-Friede et al., 2014; Zhu et al., 2014). Відбувається секреція вмісту «локусів зберігання» тромбоцитів у зовнішнє середовище (Freedman, 2011). Тромбоцити фіксуються на поверхні (наприклад, на субендотеліальному матриксі) та об'єднуються між собою та ін- 
шими клітинами крові, у першу чергу відбувається адгезія та агрегація еритроцитів, що ми виявляли особливо часто у віддалені терміни гіпокінезії.

За даними окремих авторів (Kobro, 2009; Falco et al., 2012), реєстрація агрегатограм за гіпокінезії вказує на те, що в разі стимуляції агрегації адреналіном у дозі 10 мкмоль/л у 83\% випадків спостерігається двофазна агрегація тромбоцитів, у $14 \%$ - незворотна агрегація та у $3 \%$ - після початкової агрегації спостерігається дезагрегація. Активація тромбоцитів може бути зворотною, якщо відбуваються лише часткові конформаційні зміни, нестійке об'єднання з іншими клітинами та часткова секреція гранул. Через невеликий час тромбоцит повертається в інтактний стан і продовжує циркуляцію у загальному потоку крові (Greinacher, 2011).

Після зворотної активації та повернення в неактивний стан тромбоцит знову може активуватися та вступати у взаємодію 3 іншими клітинами та структурами. Зворотна агрегація виникає за короткочасної дії слабкого за інтенсивністю стимулу. Якщо стимуляція триваліша або сильніша, відбувається незворотна активація тромбоцита (Krause et al., 2016). У цьому випадку тромбоцит міцно фіксується до інших клітин або позаклітиних структур, відбувається повна дегрануляція та секреція вмісту «локусів зберігання». Якщо тромбоцит після незвротної активації надходить у загальний кровообіг, він не може надалі вступати у взаємодію 3 іншими клітинами та швидко елімінується 3 кровообігу (Korneychuk et al., 2016). У разі масивного надходження у кровообіг незворотно активованих тромбоцитів відбувається вірогідне зниження агрегації тромбоцитів з усіма індукторами (Leavitt et al., 2007). Мікроскопія в цьому випадку дозволяє виявити велику кількість деформованих тромбоцитів. Стимулятори тромбоцитів можна поділити на слабкі та сильні.

До малоактивних стимуляторів належать АДФ, адреналін, вазопресин, серотонін тощо (Kobro et al., 2009; Bouchard et al., 2012; Arnold et al., 2013; Duan et al., 2014). Передача сигналу від рецепторів цих речовин проходить стадію посилення всередині клітини через додатковий етап утворення продуктів тромбоксанового завершення та секреції активних компонентів, що зберігаються у гранулах (Abrams et al., 2007; Bennett et al., 2014). Під час дослідження агрегації тромбоцитів за присутності слабих стимуляторів на агрегатограмах крива має двоступінчасту форму, що зумовлено посиленням агрегації після видалення вмісту «локусів зберігання» (Blair, 2009).

Сильні стимулятори тромбоцитів - колаген, тромбін, великі дози АДФ - безпосередньо після мембранної стимуляції викликають незворотну активацію (White, 2010; Whiteheart, 2011; Ware, 2012). Частина 3 найважливіших активаторів тромбоцитів присутня у підпорогових концентраціях в інтактній плазмі та вибірково накопичується в зоні пошкодження судин. Інші з'являються в системі циркуляції під час активації системи згортання крові у фізіологічних або патологічних умовах. Окремі фактори виділяються із самих тромбоцитів: АДФ, серотонін, адреналіноподібні субстанції, чинник Віллебранда (Lazarus, 2010; Hayward, 2011; Lenting and Denis, 2013).

Найважливіші фізіологічні механізми адаптації до гіпокінезіїмеханізм збудження гіпоталамо-гіпофізарної системи та посилена продукція глюкокортикоїдів і катехоламінів (Tseilikman et al., 2013; Rayes and Watson, 2015; Ruggeri, 2015). Отримані цими авторами результати підтверджують таку модель: протягом перших трьох діб адаптації у плазмі крові щурів рівень кортикостерону та адреналіну підвищується майже утричі, а вміст норадреналіну підвищується у віддалені терміни. Спостерігається вірогідне підвищення концентрації адренокортикотропного гормона через три доби з початку моделювання гіпокінезії. При цьому реалізація такого механізму відбувається за безпосередньої дегрануляції тромбоцитів (Abrams, 2007; Marks, 2012).

Таким чином, морфологічним субстратом пошкодження тромбоцитарно-еритроцитарного гемостазу у щурів різного віку за тривалої гіпокінезії виступає комплекс ультраструктурних змін клітин крові, які виникають через: 1) внутрішньо- судинну гіперактивацію тромбоцитів, 2) дисбаланс вмісту всіх типів тромбоцитарних гранул, 3) трансформацію поверхневої цитоархітектоніки еритроцитів з утворенням «ниток адгезії», 4) утворення різних за складом i розміром тромбоцитарних $\mathrm{i}$ еритроцитарних агрегатів, 5) біохімічний дисбаланс із поступовим збільшенням концентрації креатиніну та продуктів перекисного окиснення ліпідів у плазмі крові.

Цей комплекс виявляється в усіх без винятку тварин i може враховуватись як ранній предиктор розвитку можливих ускладнень гіпокінетичної хвороби. Найчутливіші кількісні характеристики вказаного комплексу - відносний вміст активованих і агрегованих тромбоцитів, щільність упаковки альфата дельта-гранул, рівень зворотно трансформованих еритроцитів, кількість тромбоцитарних агрегатів і «ниток агрегації» між окремими еритроцитами.

\section{Висновки}

У двомісячних тварин відбувається вірогідне збільшення відносного вмісту активованих тромбоцитів зі збереженням нормального вмісту агрегованих і дегранульованих форм і появою поодиноких тромбоцитів із дисбалансом альфа- та дельта-гранул.

У 12-місячних тварин порушення тромбоцитарного гемостазу полягають у вірогідному збільшенні відносного вмісту активованих тромбоцитів із підвищенням вмісту агрегованих і дегранульованих форм i появою численних тромбоцитів із дисбалансом альфа- та дельта-гранул, а також редукцією мітохондрій.

У 24-місячних тварин спостерігається різке порушення тромбоцитарного гемостазу за рахунок вірогідного наростання вмісту активованих, дегранульованих i агрегованих тромбоцитів, вивільнення вмісту більшості гранул, розвитку внутрішньосудинної гіперактивації тромбоцитів, збільшення кількості зворотно та незворотно трансформованих еритроцитів, підвищення рівня агрегації, зокрема появи складних клітинних агрегатів та химерних форм еритроцитів.

Незалежно від віку тварин ступінь порушення тромбоцитарно-еритроцитарного гемостазу підвищується у міру зростання терміну гіпокінезії, а також пов'язаний із підвищенням рівня креатиніну сироватки крові.

\section{References}

Abrams, C. S. (2007). The yin-yang of platelet granules. Blood, 111(3), 979-979. Arnold, D. M. (2013). A platelet cover-up. Blood, 122(3), 307-309.

Ali, S. F. (2015) Influence of different methods preparation on platelet activation in stored platelet concentrates. Journal of Blood Disorders and Transfusion, 6(3), 279-285.

Bennett, S. T. (2014). Validation of hemostasis assays, analyzers, and reagents. In: Laboratory Hemostasis. Springer, New York.

Blair, P. (2009). Platelet $\alpha$-granules: Basic biology and clinical correlates. Blood Reviews, 23(4), 177-189.

Bouchard, B. A., Krudysz-Amblo, J. \& Butenas, S. (2012). Platelet tissue factor is not expressed transiently after platelet activation. Blood, 119(18), 4338-4339.

Delano, M. J., Rizoli, S. B., Rhind, S. G., Cuschieri, J., Junger, W., Baker, A. J., Dubick, M. A., Hoyt, D. B., \& Bulger, E. M. (2015). Prehospital resuscitation of traumatic hemorrhagic shock with hypertonic solutions worsens hypocoagulation and hyperfibrinolysis. Shock, 44(1), 25-31.

Duan, K., Yu, W., Lin, Z., Tan, S., Bai, X., Xu, L., Dong, Y., \& Li, N. (2014). A time course study of acute traumatic coagulopathy priorresuscitation: From hypercoagulation-hypocoagulation caused by hypoperfusion? Transfusion and Apheresis Science, 50(3), 399-406.

Falco, S., Bruno, B., Maurella, C., Bellino, C., D’Angelo, A., Gianella, P., Tarducci, A., Zanatta, R., \& Borrelli, A. (2012). In vitro evaluation of canine hemostasis following dilution with hydroxyethyl starch $(130 / 0.4)$ via thromboelastometry. Journal of Veterinary Emergency and Critical Care, 22(6), 640-645.

Falet, H. (2012). Platelet size: Finding the right balance. Blood, 119(12), 2402-2403.

Freedman, J. E. (2011). A platelet transcriptome revolution. Blood, 118(14), $3760-3761$.

Gainutdinov, K. L., Andrianov, V. V., Iyudin, V. S., Yurtaeva, S. V., Jafarova, G. G., Faisullina, R. I., \& Sitdikov, F. G. (2013). EPR study of 
nitric oxide production in rat tissues under hypokinesia. Biophysics, 58(2), 203-205.

Gainutdinov, K. L., Faisullina, R. I., Andrianov, V. V., Gilmutdinova, R. I., Iyudin, V. S., Jafarova, G. G., \& Sitdikov, F. G. (2013). Nitric oxide level in the rat tissues increases after 30-day hypokinesia: Studies by electron paramagnetic resonance (EPR) spectroscopy. Bulletin of Experimental Biology and Medicine, 154(5), 635-637.

Greinacher, A. (2011). Platelet activation by heparin. Blood, 117(18), 4686-4687.

Hayward, C. P. M. (2011). Diagnostic evaluation of platelet function disorders. Blood Reviews, 25(4), 169-173.

Huang, Y., Joshi, S., Xiang, B., Kanaho, Y., Li, Z., Bouchard, B. A., Moncman, C. L., \& Whiteheart, S. W. (2016). Arf6 controls platelet spreading and clot retraction via integrin Iib 3 trafficking. Blood, 127(11), 1459-1467.

Jaeger, D. \& Jung, R. (2015). Hypokinesia model. In: Encyclopedia of computational neuroscience, 1417-1417. Springer, New York.

Juravlyova, O. A., Markin, A. A., Kuzichkin, D. S., Loginov, V. I., Zabolotskaya, I. V., \& Vostrikova, L. V. (2016). Dynamics of oxidation stress markers during long-term antiorthostatic hypokinesia: A retrospective study. Human Physiology, 42(1), 79-83.

Kasirer-Friede, A., Kang, J., Kahner, B., Ye, F., Ginsberg, M. H., \& Shattil, S. J. (2014). ADAP interactions with talin and kindlin promote platelet integrin Ilb 3 activation and stable fibrinogen binding. Blood, 123(20), 3156-3165.

Kitchen, S., \& Makris, M. (2010). Laboratory tests of hemostasis. In: Practical hemostasis and thrombosis. Blackwell Publishing Ltd.

Kobro, M. (2009). Investigations of adrenalin concentration blood. Acta Medica Scandinavica, 125(1), 1-7.

Korneychuk, S., Turner, S., Abakumov, A., \& Verbeeck, J. (2016). Determination of the platelet structure in natural diamond by ADF-STEM. European Microscopy Congress, Proceedings, 331-332.

Krause, D. S. (2016). An oxidase road-platelet adhesion. Blood, 127(11), 13861386.

Lazarus, A. H. (2010). IVIg conducts DC-platelet nuptials. Blood, 116(23), $4740-4741$.

Leavitt, A. D. (2007). What for platelet factor 4? Blood, 110(4), 1090-1090.

Lenting, P. J. \& Denis, C. V. (2013). Platelet von Willebrand factor: Sweet resistance. Blood, 122(25), 4006-4007.

Leytin, V. (2012). Apoptosis in the anucleate platelet. Blood Reviews, 26(2), 51-63.

Lieberman, L., Bercovitz, R. S., Sholapur, N. S., Heddle, N. M., Stanworth, S. J., \& Arnold, D. M. (2014). Platelet transfusions for critically all patients with thrombocytopenia. Blood, 123(8), 1146-1151.

Lutfi, M. F. (2016). Diagnostic accuracy of resting left ventricular akinesia/ hypokinesia in predicting abnormal coronary angiography. BMC Cardiovascular Disorders, 16(1), 137-140.

Makáry, A., Pataki, M., Tóth, E., \& Lusztig, G. (1987). The effect of hypoxia and hypokinesia on prostacyclin (PGI2) production of vessel wall. Experimental pathology, 32(4), 251-253.
Marcus, A. J. (2012). New approaches for measurement of platelet reactivity. Blood, 119(15), 3378-3379.

Marks, M. S. (2012). SNA Ring platelet granule secretion. Blood, 120(12), 2355-2357.

Michelson, A. D. (2013). Gray platelet syndrome. Blood, 121(2), 250-250.

Mio, K., Sato, M., \& Sato, C. (2016). Structural biology and electron microscopy. Springer Protocols Handbooks.

Naik, M. U., Caplan, J. L., \& Naik, U. P. (2013). Junctional adhesion molecule-A suppresses platelet integrin IIb 3 signaling by recruiting Csk the integrin-c-Src complex. Blood, 123(9), 1393-1402.

Neelamegham, S. (2012). The computing platelet: Integrating environmental cues. Blood, 120(1), 3-4.

Peter, K. (2010). Proteomics unravels platelet function. Blood, 115(20), 4008-4009.

Pitchford, S. C. (2015). The stop clock of platelet activation. Blood, 126(24), 2538-2539.

Rao, A. K. (2013). Spotlight on FLI1, RUNX1, and platelet dysfunction. Blood, 122(25), $4004-4006$.

Rayes, J., \& Watson, S. P. (2015). Platelet GPVI repairs its own damage. Blood, 126(8), 933-934.

Ruggeri, Z. M. (2015). Platelet GPIb: Sensing force and responding. Blood, $125(3), 423-424$.

Stogov, M. V. (2009). Creatine metabolism in skeletal muscles during hypokinesia. Bulletin of Experimental Biology and Medicine, 148(1), 26-28.

Tseilikman, V. E., Pankov, N. E., Pankova, N. A., Filimonova, T. A., Sinitskii, A. I., Kozochkin, D. A., \& Tseilikman, O. B. (2013). Correlation between circulating corticosterone and protein carbonylation in the liver after shortterm hypokinesia. Bulletin of Experimental Biology and Medicine, 156(2), $188-190$.

Vitkovsky, Y., \& Strambovskaya, N. (2014). Platelet functions in healthy persons with genetic polymorphism of GPIA(C807T), GPIIIA(T1565C), GPIBA(C434T), P2RY12(H1/H2), SELP(G1087A) platelet receptors. Thrombosis Research, 133, 83.

Ware, J. (2012). Fragmenting the platelet-reduce metastasis. Blood, 120(14), 2779-2780.

White, J. G. (2010). Platelet interior imaging technologies. Blood, 116(26), 61506151.

Whiteheart, S. W. (2011). Platelet granules: Surprise packages. Blood, 118(5), 1190-1191.

Zhu, J., Zhu, J., Bougie, D. W., Aster, R. H., \& Springer, T. A. (2015). Structural basis for quinine-dependent antibody binding-platelet integrin IIb 3. Blood, 126(18), 2138-2145.

Zorbas, Y. G., Deogenov, V. A., Merkov, P. L., \& Federenko, Y. F. (2012). Chronic periodic fluid redistribution effect on muscle calcium in healthy subjects during prolonged hypokinesia. The Journal of Physiological Sciences, 62(3), 233-239. 